\title{
The information highways of a biotechnological workhorse - signal transduction in Hypocrea jecorina Monika Schmoll
}

Address: Research Area of Gene Technology and Applied Biochemistry, Institute for Chemical Engineering, Vienna University of Technology, Getreidemarkt 9/1665, A-1060 Wien, Austria

Email: Monika Schmoll - mschmoll@mail.zserv.tuwien.ac.at

Published: 20 September 2008

BMC Genomics 2008, 9:430 doi:10.1 |86/|47|-2164-9-430

This article is available from: http://www.biomedcentral.com/I47I-2/64/9/430

(c) 2008 Schmoll; licensee BioMed Central Ltd.

This is an Open Access article distributed under the terms of the Creative Commons Attribution License (http://creativecommons.org/licenses/by/2.0), which permits unrestricted use, distribution, and reproduction in any medium, provided the original work is properly cited.
Received: 18 March 2008

Accepted: 20 September 2008

\begin{abstract}
Background: The ascomycete Hypocrea jecorina (anamorph Trichoderma reesei) is one of the most prolific producers of biomass-degrading enzymes and frequently termed an industrial workhorse. To compete for nutrients in its habitat despite its shortcoming in certain degradative enzymes, efficient perception and interpretation of environmental signals is indispensable. A better understanding of these signals as well as their transmission machinery can provide sources for improvement of biotechnological processes.
\end{abstract}

Results: The genome of $H$. jecorina was analysed for the presence and composition of common signal transduction pathways including heterotrimeric G-protein cascades, cAMP signaling, mitogen activated protein kinases, two component phosphorelay systems, proteins involved in circadian rhythmicity and light response, calcium signaling and the superfamily of Ras small GTPases. The results of this survey are discussed in the context of current knowledge in order to assess putative functions as well as potential impact of alterations of the respective pathways.

Conclusion: Important findings include an additional, bacterial type phospholipase $C$ protein and an additional 6-4 photolyase. Moreover the presence of 4 RGS-(Regulator of G-protein Signaling) proteins and 3 GprK-type G-protein coupled receptors comprising an RGS-domain suggest a more complex posttranslational regulation of G-protein signaling than in other ascomycetes. Also the finding, that $H$. jecorina, unlike yeast possesses class $I$ phosducins which are involved in phototransduction in mammals warrants further investigation. An alteration in the regulation of circadian rhythmicity may be deduced from the extension of both the class I and II of casein kinases, homologues of which are implicated in phosphorylation of FRQ in Neurospora crassa. On the other hand, a shortage in the number of the pathogenicity related PTHII-type G-protein coupled receptors (GPCRs) as well as a lack of microbial opsins was detected. Considering its efficient enzyme system for breakdown of cellulosic materials, it came as a surprise that $H$. jecorina does not possess a carbon sensing GPCR.

\section{Background}

Hypocrea jecorina (anamorph Trichoderma reesei) was first isolated in the tropics during the Second World War and is found in soils, feeding on decaying wood and decom- posing plant matter [1]. Since then strains of $H$. jecorina have been isolated from numerous habitats around the world. Its natural habitat indicates an evolution of $\mathrm{H}$. jecorina towards recognition of substrates comprising cellu- 
lose and hemicellulose, which requires development of an adequate signal transduction machinery to optimize energy consumption against energy (substrate-) availability. This speciation led to the highly efficient cellulase and hemicellulase production of this fungus, which is presently also exploited by the biotechnological industry [24]. $H$. jecorina therefore has become a paradigm for the enzymatic breakdown of cellulose and hemicellulose, but is also known as a potent host for heterologous protein production due to its strong inducible promotors $[5,6]$. Despite the industrial utility and effectiveness of these carbohydrate-active enzymes of $H$. jecorina, a surprisingly small set of cellulases, hemicellulases and pectinases is available in its genome [7]. Also the number of enzymes comprising a carbonhydrate binding module in $\mathrm{H}$. jecorina is the lowest among Sordariomycetes analysed so far. Nevertheless, this limited enzyme set obviously does not cause an evolutionary disadvantage in competition with other cellulose and hemicellulose-degrading fungi. Since in some cases in H. jecorina glycoside hydrolase genes are clustered near genes encoding proteins involved in secondary metabolite production, it is tempting to speculate that the success of $H$. jecorina might be connected to efficient control of expression of genes belonging to these groups [7].

Apart from studies on the properties of these enzymes and their regulation (for reviews see $[5,6,8]$ ), there has been a continuing interest in understanding the role of fungi in the carbon turn over in nature generally as well as of the physiology of the organism and its interrelationship with its environment. Accordingly, $H$. jecorina has recently also been used to study the significance of carbon catabolite derepression and cellulase gene expression for the antagonization of phytopathogenic fungi and suggested to be used as a model organism for related studies [9].

Crucial for the prosperity of any organism is the ability to survive under various conditions as well as to rapidly and appropriately react to a changing environment, which is mainly accomplished through an efficient signaling machinery $[10,11]$. The tight regulation of the numerous enzymes expressed by $H$. jecorina as well as its broad industrial applicability suggest a sophisticated signal transduction system, which provides the fungus with a tool kit for adjusting to such different environments as the soil of a tropic forest and a shake flask culture with a minimal medium. Nevertheless, while characteristics and regulation of the hydrolytic enzymes have been subject to numerous studies for decades now, analysis of the signal transduction machinery of $H$. jecorina is still in its start-up phase. To date, only one signal transduction protein has been analyzed on a molecular level: ENVOY, a PAS/LOV domain protein is crucial for light tolerance in $H$. jecorina and is involved in regulation of cellulase gene expression
[12]. A recent study moreover indicates that this protein has a more widespread function than only regulation of processes related to light response in that it shows that ENVOY influences transcription of genes with various functions and does so not only in light but also during growth in darkness [13]. Besides that, only one earlier study dealt with a signaling event in $H$. jecorina: Mach and coworkers [14] showed that calmodulin-antagonists interfere with xylanase formation and secretion and thereby provided a first hint as to the significance of $\mathrm{Ca}^{2+}$ signaling in this fungus.

However, the availability of the sequenced genome of $H$. jecorina [15] now opens new possibilities for investigating the potential of this fungus to perceive and interpret the signals from its environment. Gene modeling revealed 9129 gene models for $H$. jecorina [7], which is relatively close to the number of gene models in N. crassa [16], but is roughly 2500 fewer than the number of predicted genes in Fusarium graminearum [17]. Based on in depth analysis of the genome of $H$. jecorina, this study therefore intends to provide a basis for further investigation of signal transduction pathways by placing the $H$. jecorina orthologues of members of common signaling cascades described in other organisms in a genomic perspective. Characterized functions of those genes are shown together with the background of previous studies in H. jecorina and ascomycetes in general. Consequently a first map of the signaling landscape is laid out which shows both common highways as well as uncharted territories with islands reflecting the individuality of this organism.

\section{Results and Discussion \\ Heterotrimeric G-protein signaling}

Heterotrimeric G-proteins, comprising alpha-, beta- and gamma-subunits, are essential components of the signal transduction machinery in eukaryotic cells $[18,19]$. They transduce signals received by the heptahelical G-protein coupled receptors (GPCRs) from outside the cell and impact numerous regulatory pathways via their respective effectors, which in turn effect activity of secondary messengers $[20,21]$. The G-alpha subunit is tightly associated with the respective G-beta and -gamma subunit and binds GDP in its inactive state. Upon activation following binding of a ligand to its corresponding GPCR, GDP is exchanged for GTP and the G-alpha subunit dissociates from the G-beta-gamma heterodimer. Both parts are then free to activate their downstream targets [22]. With the increasing number of sequenced genomes of filamentous ascomycetes also a broad overview of the components of the heterotrimeric G-protein signaling pathway became available and several studies now provide a comprehensive summary on this topic (for example $[23,24]$ ). While heterotrimeric G-protein signaling has been studied extensively in several fungi including closely related Tri- 
choderma spp. and has been implicated in such diverse processes as hyphal growth, conidiation, stress responses, chitinase formation, carbon source sensing, production of antifungal metabolites and mycoparasitic coiling [25-31] the functions of the $H$. jecorina homologues are not yet known.

Analysis of the genome revealed that $H$. jecorina has three G-alpha subunits, one G-beta subunit and one G-gamma subunit (Table 1), which corresponds well with the data of Neurospora crassa [25] and many other filamentous fungi [24]. However, considering the presence of 125 proteins comprising G-beta like WD-repeats in the genome of $H$. jecorina, of which 22 are not synthenic in F. graminearum [7], it cannot be excluded that further functional Gbeta subunits exist, albeit as in other fungi, no evidence for interaction with G-alpha subunits or a function comparable to G-beta subunis of these proteins is available. While both G-alpha and G-beta subunits are well conserved in the fungal kingdom, the G-gamma subunit only shares low similarity to its nearest neighbours (Table 1). A phylogenetic analysis (Figure 1A) showed that the Galpha subunits cluster well with the corresponding proteins of other fungi. The two closest homologues of the fourth G-alpha protein of Ustilago maydis [32], tre38187 and tre43177, which comprise GTP binding domains altered similarly to Gpa4 and unaltered GTPase domains (Figure 1B), were included in this analysis. However, these proteins did not cluster with Gpa4, but rather represent an outgroup in this tree. Consequently it is unlikely that tre38187 and tre43177 are functional G-alpha proteins, although experimental evidence remains to prove this hypothesis. Also a search for homologues of the fourth G-alpha subunit of Aspergillus oryze, GaoC [23] did not reveal a further $\mathrm{G}$-alpha subunit in $H$. jecorina. Harashima and Heitmann [33] reported on G-protein beta mimics in Saccharomyces cerevisiae which contain 7 kelch repeats and bind to the G-alpha protein Gpa2p. These proteins (Gpb1p and Gpb2p) also assume a function in regulation of filamentous growth in $S$. cerevisiae. While initially considered G-beta and G-gamma mimics they are now rather considered effectors of Gpa2p [34]. In H. jecorina, several Kelch-repeat proteins have been found, but none of them contained 7 Kelch repeats or showed any similarity to Gpb1p or Gpb2p. Also for the described $S$. cerevisiae G-gamma mimic Gpg1p no homologue was found. Consistently, such G-beta or G-gamma mimics/Galpha effectors have not been found in other filamentous fungi so far.

\section{G-protein coupled receptors}

The signal to be transmitted through a heterotrimeric Gprotein signaling cascade is received by the plasma-membrane localized G-protein coupled receptors. Screening the $H$. jecorina genome for heptahelical transmembrane G-protein coupled receptors revealed a total of 34 such proteins. They represent members of all but two classes of GPCRs defined in filamentous fungi [24] (Table 2). Besides the two pheromone receptors (tre18617 and tre19688), two members of the class of Stm1-like putative nitrogen sensors and one orthologue of the rat growth hormone releasing factor homologue MG00532 of Magnaporthe grisea were detected. However, in contrast to other ascomycetes, no members of the group of microbial

Table I: Heterotrimeric G-protein signaling

\begin{tabular}{|c|c|c|c|c|c|c|c|c|c|c|}
\hline & $\begin{array}{l}\text { Best hit } \\
\text { overall }\end{array}$ & S. cerevisiae & S. pombe & Animal & $\begin{array}{c}\text { Plant } \\
\text { (Viridiplantae } \\
\text { limited) }\end{array}$ & Neurospora & Aspergillus & Fusarium & Magnaporthe & Cryphonectria \\
\hline GNAI & $\begin{array}{c}\text { Hypocrea virens } \\
\text { G-protein } \\
\text { alpha subunit, } \\
0.0,100 \% \\
\text { (AA018659.1) }\end{array}$ & $\begin{array}{c}\text { Gpa2p, 2e-75, } \\
43 \%, \\
\text { (NP_010937.I) }\end{array}$ & $\begin{array}{c}\text { gpal, 2e-7I, } \\
42 \%, \\
\text { (CAA2III50.I) }\end{array}$ & $\begin{array}{c}\text { Rattus norvegicus } \\
\text { Gnai2, 4e-105, } \\
55 \%, \\
\text { (NP_II } \\
\text { (N297.I) }\end{array}$ & $\begin{array}{c}\text { Oryza sativa } \\
\text { GPA-I, 2e-52, } \\
37 \% \\
\text { (AAV43839.I) }\end{array}$ & $\begin{array}{c}\text { Neurospora } \\
\text { crassa GNA-I, } \\
0.0,96 \%, \\
\text { (AAA02560.I) }\end{array}$ & $\begin{array}{c}\text { Aspergillus } \\
\text { fumigatus } \\
\text { GpaA, 0.0, 94\% } \\
\text { (EAL90646.I) }\end{array}$ & $\begin{array}{c}\text { Gibberella zeae } \\
\text { PH-I, GBAI, } \\
0.0,98 \% \\
\text { (EAA75079.I) }\end{array}$ & $\begin{array}{c}\text { Magnaporthe } \\
\text { grisea MAGB, } \\
0.0,97 \%, \\
\text { (AAB65426.I) }\end{array}$ & $\begin{array}{c}\text { Cryphonectria } \\
\text { parasitica GPAI, } \\
0.0,98 \%, \\
(\mathrm{Q} 00580)\end{array}$ \\
\hline GNA2 & $\begin{array}{l}\text { Hypocrea virens } \\
\text { G-protein } \\
\text { alpha subunit, } \\
0.0,94 \% \\
\text { (AAN65।82.I) }\end{array}$ & $\begin{array}{c}\text { Gpa2p, 3e-66, } \\
41 \%, \\
\text { (NP_0I0937.I) }\end{array}$ & $\begin{array}{c}\text { gpal, 7e-82, } \\
47 \% \\
\text { (CAA2II50.I) }\end{array}$ & $\begin{array}{c}\text { Canis familiaris } \\
\text { Guanine } \\
\text { nucleotide- } \\
\text { binding protein } \\
\mathrm{G}(\mathrm{t}), \mathrm{alpha-3} \\
\text { subunit, } 8 \mathrm{e}-89, \\
48 \%, \\
\text { (XP849666.l) }\end{array}$ & $\begin{array}{c}\text { Pisum sativum } \\
\text { GPA2, 3e-52, } \\
35 \%, \\
\text { (AAM97353.I) }\end{array}$ & $\begin{array}{c}\text { Neurospora } \\
\text { crassa GNA-2, } \\
4 \mathrm{e}-163,78 \% \\
\text { (CAD7I } 253.1 \text { ) }\end{array}$ & $\begin{array}{c}\text { Aspergillus } \\
\text { fumigatus } \\
\text { GanA, 3e-105, } \\
53 \% \\
\text { (EAL92343.I) }\end{array}$ & $\begin{array}{c}\text { Gibberella zeae } \\
\text { PH-I, } \\
\text { hypothetical } \\
\text { protein } \\
\text { FG09988.I, Ie- } \\
169,79 \% \\
\text { (EAA69333.I) }\end{array}$ & $\begin{array}{l}\text { Magnaporthe } \\
\text { grisea MAGC, } \\
9 \mathrm{e}-162,77 \% \text {, } \\
\text { (AAB65427.I) }\end{array}$ & $\begin{array}{c}\text { Cryphonectria } \\
\text { parasitica CPG- } \\
3,6 \mathrm{e}-163,77 \% \\
\text { (AAMI } 4395 \text { ) }\end{array}$ \\
\hline GNA3 & $\begin{array}{c}\text { Trichoderma } \\
\text { atroviride Tga3, } \\
0.0,96 \% \\
\text { (AAM69919.I) }\end{array}$ & $\begin{array}{c}\text { Gpa2p, 8e-105, } \\
53 \%, \\
\text { (NP_010937.I) }\end{array}$ & $\begin{array}{c}\text { gpa2, 2e-83, } \\
45 \%, \\
(\mathrm{Q} 04665)\end{array}$ & $\begin{array}{c}\text { Drosophila } \\
\text { melanogaster } \\
\text { GNAI, 4e-88, } \\
48 \% \text {, (P20353) }\end{array}$ & $\begin{array}{c}\text { Glycine max } \\
\text { GPA-2, 5e-54, } \\
33 \% \text { (P93।63) }\end{array}$ & $\begin{array}{c}\text { Neurospora } \\
\text { crassa GNA-3, } \\
0.0,91 \% \\
\text { (EAA76506.I) }\end{array}$ & $\begin{array}{c}\text { Aspergillus } \\
\text { fumigatus } \\
\text { GpaB, le-154, } \\
75 \% \\
\text { (EAL90625.I) }\end{array}$ & $\begin{array}{c}\text { Fusarium } \\
\text { oxysporum fga I, } \\
0.0,90 \% \\
\text { (BAD44729.I) }\end{array}$ & $\begin{array}{c}\text { Magnaporthe } \\
\text { grisea MAGA, } \\
0.0,87 \% \text {, } \\
\text { (AAB65425.I) }\end{array}$ & $\begin{array}{c}\text { Cryphonectria } \\
\text { parasitica GPAI, } \\
\text { Ie-93, 49\%, } \\
\text { (Q00580) }\end{array}$ \\
\hline GNBI & $\begin{array}{c}\text { Trichoderma } \\
\text { atroviride } \\
\text { TGBI, 0.0, } \\
98 \%, \\
\text { (AA037685.I) }\end{array}$ & $\begin{array}{c}\text { Ste4, G-protein } \\
\text { beta subunit, Ie- } \\
72,37 \% \\
\text { (PI885I) }\end{array}$ & $\begin{array}{c}\mathrm{gpbl}, 3 \mathrm{e}-73 \\
44 \% \\
(\mathrm{Q} 10282)\end{array}$ & $\begin{array}{c}\text { Caenorhabditis } \\
\text { elegans gpb-I, } \\
\text { 2e-137,69\% } \\
\text { (PI7343) }\end{array}$ & $\begin{array}{c}\text { Oryza sativa } \\
\text { GBB, Ie-97,48\% } \\
\text { (Q40687) }\end{array}$ & $\begin{array}{c}\text { Neurospora } \\
\text { crassa GNB-I, } \\
0.0,91 \% \\
\text { (AAM53552.I) }\end{array}$ & $\begin{array}{c}\text { Aspergillus } \\
\text { nidulans GBB, } \\
5 \mathrm{e}-174,84 \% \\
(\mathrm{XP} 657685.1)\end{array}$ & $\begin{array}{c}\text { Fusarium } \\
\text { oxysporum fgb I, } \\
0.0,98 \%, \\
\text { (AA091808.I) }\end{array}$ & $\begin{array}{c}\text { Magnaporthe } \\
\text { grisea Mgbl, } 0.0 \\
95 \% \\
\text { (BAC0I I65.I) }\end{array}$ & $\begin{array}{c}\text { Cryphonectria } \\
\text { parasitica GB-I, } \\
0.0,94 \% \\
(\mathrm{O} \mid 4435)\end{array}$ \\
\hline GNGI & $\begin{array}{c}\text { Gibberella zeae } \\
\text { PH-I, } \\
\text { conserved } \\
\text { hypothetical } \\
\text { protein, 2e-35, } \\
95 \% \\
\text { (EAA77833.I) }\end{array}$ & None & None & None & None & $\begin{array}{c}\text { Neurospora } \\
\text { crassa GBGI, } \\
5 \mathrm{e}-25,81 \% \\
\text { (Q7RWTO) }\end{array}$ & $\begin{array}{c}\text { Aspergillus } \\
\text { nidulans } \\
\text { hypothetical } \\
\text { protein } \\
\text { AN2742.2, 2e- } \\
17,67 \% \\
(\mathrm{XP} 660346.1)\end{array}$ & $\begin{array}{c}\text { Gibberella zeae } \\
\text { PH-I, } \\
\text { conserved } \\
\text { hypothetical } \\
\text { protein, 2e-35, } \\
95 \% \\
\text { (EAA77833.I) }\end{array}$ & $\begin{array}{c}\text { Magnaporthe } \\
\text { grisea } \\
\text { hypothetical } \\
\text { protein } \\
\text { MG10193.4, 6e- } \\
32,84 \% \\
\left(X P \_365973.1\right)\end{array}$ & None \\
\hline
\end{tabular}

Nearest neighbours of the respective organisms are listed along with E-value as determined by NCBI blastp search, percent identities within fragment and GenBank accession number. 
opsins or an opsin-related protein similar to $N$. crassa NOP-1 or ORP-1 is present. These proteins function as light responsive ion pumps or sensory receptors [25]. Analysis of N. crassa NOP-1 revealed a function in modulation of carotenogenesis and regulation of conidiation specific genes and represents a putative green light photoreceptor, which is regulated by WC-2 [35-37]. The significance of this shortcoming in $H$. jecorina is difficult to assess, since despite a lack of banding without light pulses, conidiation still responds to light and this fungus is not reported to produce carotenoids. Also a GPCR similar to the glucose sensors found in S. cerevisiae, S. pombe and the carbon sensor GPR- 4 of $N$. crassa $[24,25,38,39]$ is not present in the genome of $H$. jecorina. The genomic locus of the $H$. jecorina homologue of $N$. crassa GPR-4 (NCU06312.3) obviously has been lost, because the genes flanking the locus of this receptor in $N$. crassa (NCU06311.3 and NCU06314.2) are synthenic in H. jecorina, N. crassa and F. solani [40], while GPR-4 and NCU06313.3 have no homologues in $H$. jecorina. Instead, it seems that an insertion has occurred resulting in a non synthenic region comprising putative genes with low similarity to genes of filamentous fungi. On the other hand, the groups of cAMP-receptor like proteins ( 5 members) as well as the group of GPCRs related to the H. sapiens mPRlike protein ( 5 members) and the class of Aspergillus GprKlike receptors [23], which comprise an RGS domain (3 members), are expanded in comparison with other filamentous fungi [24]. The large family of PTH11-receptors (21 members in N. crassa and considerably more in the plant pathogens Magnaporthe grisea (60) and Fusarium graminearum (105)) is present with numbers in the range of the saprophytic $N$. crassa and thus clearly underrepresented in H. jecorina with only 16 members as compared to pathogenic fungi. This is the lowest number of these proteins present in the filamentous fungi analyzed to date [24]. The shortage of these GPCRs originally identified as pathogenicity-related in Magnaporthe grisea [41,42] could be indicative of a saprophytic/non pathogenic life style considering the also lower number of these receptors in $N$. crassa.

\section{Regulation of G-protein signaling}

Regulation of the intensity of a G-protein mediated signal is mainly accomplished by the action of phosducins or regulators of G-protein signaling (RGS-proteins) [43-45]. Phosducins modulate the activity and availability of the G-beta-gamma complex and are reported to be positive regulators of G-beta function. However, recent data overturned the initial hypothesis [46,47] that phosducin would block $\mathrm{G}$ protein signaling by disrupting the interaction between G-protein alpha subunits and the G-betagamma dimer. The current understanding of phosducinfunction rather suggests a regulatory influence as an essential cochaperone of G-beta-gamma folding [48-50]. In fil- amentous fungi two studies in Cryphonectria parasitica [44] and Aspergillus nidulans [45] revealed that deletion of the respective phosducin results in a phenotype similar to deletion mutants in the respective G-beta subunit, an effect also seen with Dictyostelium discoideum [51]. In order to assess the position of the two $H$. jecorina phosducins (tre80048 and tre29008) within the classification as defined by Blaauw et al., [51], a phylogenetic analysis with a subset of the proteins used in this study together with the phosducin-homologues of several ascomycetous fungi and those of $H$. jecorina was performed (Figure 2). This analysis revealed that filamentous ascomycetes possess members of the class II phosducins, but - in contrast to $S$. cerevisiae - they also have class I phosducins, whereas only in A. nidulans members of class III of phosducin-like proteins as in $S$. cerevisiae were found (Table 3 ). These class I phosducins - with the exception of the M. grisea protein - also comprise an N-terminal region with high similarity to the 11 aa sequence conserved between the two Homo sapiens subgroup I phosducins Pdc and PhlP1 [52], which is a major interaction site of the transducin Gbetagamma dimer [53] (Figure 3). Consequently, it remains to be shown whether the function of these proteins is executed as cochaperones as could be assumed if they are homologues of PhlP1 or rather resembles the function of Pdc, i. e. to ensure efficient translocation of the G-beta-gamma dimer during light and dark adaptation [50]. Since light response or -adaptation has not been reported in S. cerevisiae and homologues of subclass I have not been detected in this ascomycete, the elaborate studies on yeast phosducins [54] cannot contribute to an elucidation of the underlying mechanism in other, filamentous ascomycetes.

Regulators of G-protein signaling have an enhancing effect on the intrinsic GTPase activity of G-alpha subunits and thus can cause termination of the mediated signal [55]. Comparably to A. nidulans [56], H. jecorina possesses orthologues of all four RGS-proteins of A. nidulans (tre38047, tre78314, tre65607 and RGS1 corresponding to RgsA, RgsB, RgsC and FlbA, respectively). Interestingly, $H$. jecorina also possesses 3 homologues of the A. nidulans RGS-domain containing G-protein coupled receptor GprK (tre37525, tre63981 and tre81383), which is the highest number of these proteins in all fungi screened to date [24]. Consequently, it appears that $H$. jecorina applies tight control on the signals to be transmitted via the heterotrimeric G-protein signaling cascade. That could indicate that $\mathrm{H}$. jecorina executes a thorough determination of the significance of the respective signal for its downstream targets under certain environmental conditions.

Adjustment of the duration of a GPCR-mediated signal is executed by $\beta$-arrestins, which have predominantly been 


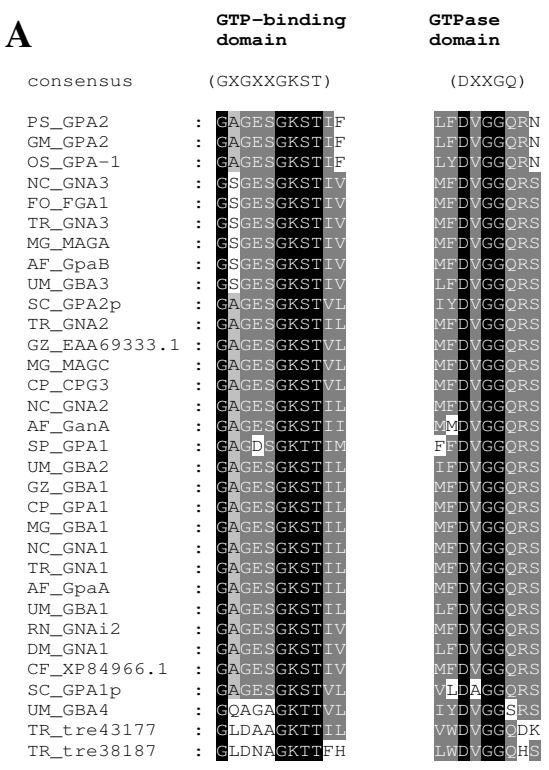

B

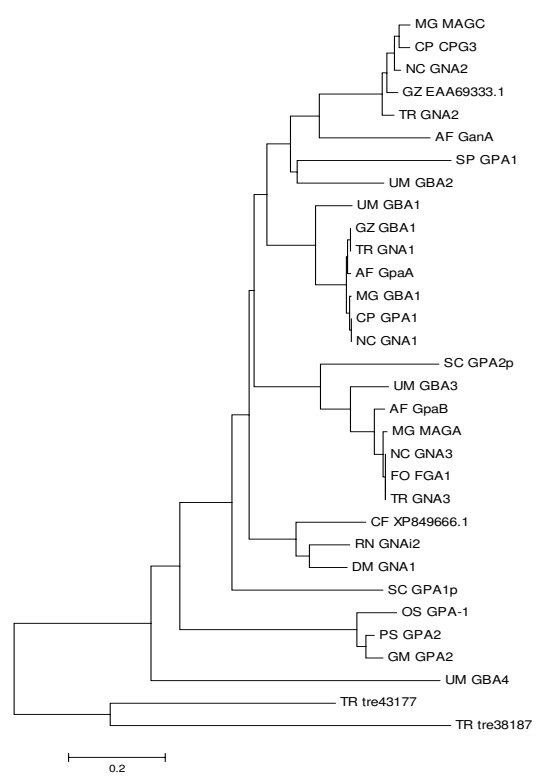

\section{Figure I}

Alignment and phylogenetic analysis of G-protein alpha subunits. The $H$. jecorina genome comprises 3 G-alpha subunits belonging to the three subgroups common in other fungi. Accession numbers (corresponding database: GenBank) of the protein sequences used are those of the nearest neighbours of Trichoderma reesei (Hypocrea jecorina) (TR) in Saccharomyces cerevisiae (SC), Schizosaccharomyces pombe (SP), Neurospora crassa (NC), Aspergillus fumigatus (AF), Gibberella zeae (GZ), Fusarium oxysporum (FO), Magnaporthe grisea (MG), Cryphonectria parasitica (CP), Rattus norvegicus (RN), Canis familiaris (CF), Drosophila melaongaster (DM), Oryza sativa (OS), Pisum sativum (PS) and Glycine max (GM), are as listed in Table I. Accession numbers (corresponding database: GenBank) of the G-protein alpha subunits of Ustilago maydis (UM) are: GPAI P87032, GPA2 P87033, GPA3 P87034 and GPA4 P87035. (A) Alignment of GTP-binding domains and GTPase domains of G-protein alpha subunits including the two additional putative G-protein alpha subunits of $H$. jecorina (tre43I77 and tre38I87). While the GTPase domain of these two proteins matches the consensus (DXXGQ), the GTP binding domain is altered at the same position as in U. maydis Gpr4p (GXGXXGKS/T) [32]. (B) Phylogenetic analysis of G-alpha subunits using the Minimum evolution method and 500 Bootstrap replications as test of phylogeny. 
Table 2: G-protein coupled receptors of $H$. jecorina

\begin{tabular}{|c|c|c|}
\hline function & type & ID \\
\hline \multirow[t]{2}{*}{ Pheromone receptors } & Ste2 & tre 18617 \\
\hline & & Ste3 \\
\hline \multirow[t]{5}{*}{ CAMP-receptor like proteins } & & tre29339 \\
\hline & & tre36247 \\
\hline & & tre59778 \\
\hline & & tre72004 \\
\hline & & tre72627 \\
\hline carbon sensors & & none \\
\hline \multirow[t]{2}{*}{ putative nitrogen sensors } & Stm I-like & tre80I25 \\
\hline & & tre4508 \\
\hline \multicolumn{2}{|l|}{ microbial opsins } & none \\
\hline \multirow[t]{5}{*}{ related to $H$. sapiens mPR- like proteins } & mPR-like & tre56426 \\
\hline & & tre68212 \\
\hline & & tre70139 \\
\hline & & tre82246 \\
\hline & & trel19819 \\
\hline related to rat growth hormone releasing factor & M. grisea MG00532-like & tre456 \\
\hline \multirow[t]{3}{*}{ GPCR comprising RGS-domain } & Aspergillus GprK-like & tre37525 \\
\hline & & tre6398I \\
\hline & & tre8I383 \\
\hline \multirow[t]{16}{*}{ implicated in pathogenesis in Magnaporthe grisea } & PTHII-type & $\operatorname{tre} 5647$ \\
\hline & & tre27983 \\
\hline & & tre27992 \\
\hline & & tre4I 260 \\
\hline & & tre45573 \\
\hline & & tre5556I \\
\hline & & tre57I0I \\
\hline & & tre62462 \\
\hline & & tre 69500 \\
\hline & & tre76763 \\
\hline & & tre 103694 \\
\hline & & tre 107042 \\
\hline & & trell 10339 \\
\hline & & trell I 861 \\
\hline & & trel 21990 \\
\hline & & tre $|24| 13$ \\
\hline
\end{tabular}

Classification was applied according to [24]

studied in higher organisms $[57,58]$. They contribute to the desensitization of the GPCR after phosphorylation by G-protein coupled receptor kinases (GRKs) and thus promote termination of the G-alpha signal. Two candidate genes encoding potential $\beta$-arrestins were detected (tre14071 and tre39560), which have homologues in Gibberella zeae, M. grisea, N. crassa and A. nidulans. Among them are the $A$. nidulans $\mathrm{pH}$-response regulator protein PalF (E-value 2E-103; [59]) and the A. nidulans carbon catabolite repressor protein CreD (E-value 2E-72; [60]). However, despite several proteins related to mammalian $\mathrm{G}$-protein coupled receptor kinases, no protein of $\mathrm{H}$. jecorina bearing a GPCR kinase domain (IPR000239) was found. Therefore the mentioned phosphorylation step 
Table 3: Classification of phosducin proteins in ascomycetes as deduced from phylogenetic analysis

\begin{tabular}{cccc}
\hline Organism & Class I & Class II & Class III \\
\hline Hypocrea jecorina & tre29008 & tre80048 \\
Gibberella zeae & XP_38428I.I & XP_386582 & XP_001409912.1 \\
Magnaporthe grisea & XP_357577.2 & XP_965767.I & XP_956705 \\
Neurospora crassa & XP_65760135 \\
Aspergillus nidulans & XP_65768.1 & Q12017 & NP_010469 \\
Saccharomyces cerevisiae & & & \\
\hline
\end{tabular}

might be executed by a different kinase or alternatively the H. jecorina GRKs share only low homology with GRKs characterized so far.

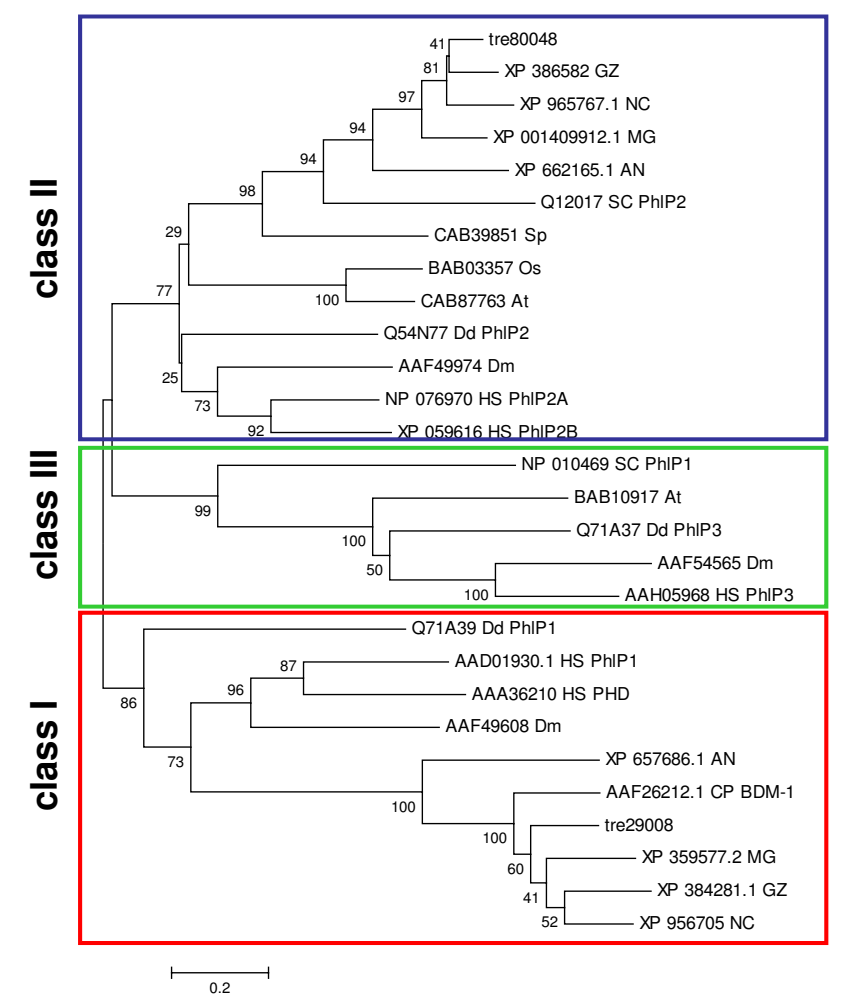

Figure 2

Phylogenetic analysis of phoducin-like proteins. In contrast to $S$. cerevisiae, $H$. jecorina and other filamentous ascomycetes possess class I phosducin-like proteins, but no class III phosducin-like proteins. GenBank accession numbers of the protein sequences used are those of the nearest neighbours of Trichoderma reesei (Hypocrea jecorina) (treXXXXX) in Saccharomyces cerevisiae (SC), Schizosaccharomyces pombe (SP), Neurospora crassa (NC), Aspergillus nidulans (AN), Gibberella zeae (GZ), Magnaporthe grisea (MG), Cryphonectria parasitica (CP), Dictyostelium discoideum (Dd), Drosophila melaongaster (DM), Oryza sativa (OS), Homo sapiens (HS) and Arabidopsis thaliana (At). The analysis was performed using the Minimum Evolution method and 500 Bootstrap replications as test of phylogeny.

\section{cAMP signaling}

Cyclic AMP was found to activate a variety of glucoserepressed functions, including catabolism of carbon sources but also to control numerous often apparently unrelated functions in animal cells. Thus cAMP was initially proposed as a primitive signal for carbon starvation, although also its effects on development and other specific responses have been subject to extensive analyses since. In fungi, its effects reach from the control of utilization of endogenous and exogenous carbon sources and conidiation in N. crassa, dimorphism and sexual development in several fungi and phototropism in Phycomyces $[10,61]$. Addition of cAMP to cultures of Trichoderma atroviride induces mycoparasitism-related coiling around simulated host-hyphae even in the absence of lectins [28]. Crosstalk of the CAMP signaling pathway with the light perception machinery has been reported in $T$. atroviride $[62,63]$. In $H$. jecorina addition of cAMP can double the efficacy of sophorose induction of endoglucanase formation [64], but this effect decreases if the concentration exceeds the optimum. In yeast, the addition of a rapidly fermented sugar to derepressed cells initiates a rapid, transient spike in the cAMP level [65] and intracellular acidification stimulates CAMP synthesis [66], although the respective physiological role has remained enigmatic. The studies of Farkas and coworkers [67], Sestak and Farkas [64] and Montenecourt [68] on the correlation of intracellular cAMP-levels and cellulase formation during growth on different carbon sources did not yield consistent results. Nevertheless, they suggest that CAMP might be an important signal for regulation of cellulase formation, but not the only one. Analysis of intracellular cAMP-levels revealed a significant increase in response to a light pulse [69], which is in concordance with the finding of a light activated adenylyl cyclase in Trichoderma viride [70]. This intracellular concentration of CAMP is determined by the balance between the activities of adenylyl cyclase and 3'5' cyclic AMP phosphodiesterase. In yeast, Ras small GTPases have been implicated in regulation of the cAMP pathway and suggested to regulate adenylate cyclase [66]. However the precise mechanism of this influence has not been established yet. The importance of cAMP signaling for $H$. jecorina is highlighted by the finding of 5 putative cAMP-GPCRs. However, the reception of cAMP as an envi- 


$\begin{array}{ll}\text { AAD 01930.1 } & \text { HS_PhIP1 } \\ \text { AAA36210 } & \text { HS_PHD } \\ \text { tre29008 } & \\ \text { XP_384281.1 } & \text { GZ } \\ \text { XP_359577.2 } & \text { MG } \\ \text { AAF26212.1 } & \text { CP_BDM-1 } \\ \text { XP_956705 } & \text { NC } \\ \text { XP_657686.1 } & \text { AN } \\ \text { Q71A39 } & \text { Dd_PhIP1 }\end{array}$

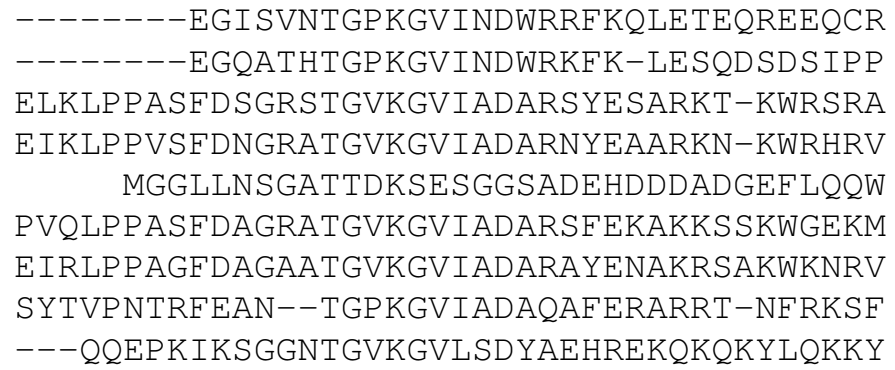

Figure 3

Alignment of regions similar to the G-beta-gamma binding conserved helix I of Homo sapiens PhIP I and Pdc in filamentous ascomycetes. The conserved sequence is given in bold for Trichoderma reesei (Hypocrea jecorina) (treXXXXX), Neurospora crassa (NC), Aspergillus nidulans (AN), Gibberella zeae (GZ), Magnaporthe grisea (MG), Cryphonectria parasitica (CP), Dictyostelium discoideum (Dd), and Homo sapiens (HS).

ronmental signal by a GPCR in filamentous fungi remains to be proven.

The genome of $H$. jecorina comprises one adenylyl cyclase (ACY1), one adenylyl cyclase associated protein (tre22793), one low affinity cyclic nucleotide phosphodiesterase (tre35876) and one high affinity cyclic nucleotide phosphodiesterase (tre32709). Similarly to N. crassa, $H$. jecorina possesses 2 protein kinase A catalytic subunits (PKAC1 and PKAC2) and one regulatory subunit (PKAR1). The hypothesis that CAMP or a related molecule could act as an environmental signal and initiate a signaling cascade by binding to a GPCR as suggested for $N$. crassa [25] is corroborated by the findings for $H$. jecorina, albeit such a function has not yet been shown for any filamentous fungus.

\section{Mitogen activated protein kinases (MAP kinases)}

Mitogen activated protein kinase (MAP kinase) pathways represent one of the most prominent signal transduction systems. The respective signaling cascades comprise three serine/threonine protein kinases that act in series: MAP kinase kinase kinase (MAPKKK), MAP kinase kinase (MAPKK) and MAP kinase (MAPK) [71,72]. The signaling output of these cascades often targets transcription factors and is reported to be interconnected with cAMP-signaling $[10,73]$ and heterotrimeric G-protein signaling [74,75]. MAP-kinases are essential for appressorium formation and virulence in $M$. grisea [76,77] and for fungal pathogenicity $[78,79]$. On the other hand, MAP-kinases are also important for plant systemic resistance, biocontrol of pathogenic fungi and mycoparasitism as shown for several Trichoderma spp. [80-83]. In N. crassa functions range from sexual development and hyphal fusion [84,85], osmosensitivity and resistance to fungicides [86-88] to circadian rhythmicity via the HOG1-orthologue OS-2 [89].
The most extensively studied example of the MAP kinase signaling system are the pathways of $S$. cerevisiae $[71,72]$, the major functions of which are in osmosensing, filamentation, cell integrity, spore wall assembly and pheromone signaling.

Based on their homologues in S. cerevisiae and the pathways determined in this fungus [72] as well as according to the interaction partners of the respective kinases as determined using the Database of interacting proteins (DIP services [90]) a model for the putative MAP kinase cascades in $H$. jecorina was assembled (Figure 4). In $H$. jecorina, nine members of MAP-kinase cascades were identified, none of which has been characterized yet. The functions suggested for these pathways were assigned based on characterized homologues of the members of the cascades. Interestingly, in contrast to $S$. cerevisiae, which comprises five MAP kinase cascades, H. jecorina - similar to other filamentous ascomycetes - apparently only has three, for which functions in (i) pheromone response and biocontrol, (ii) stress response and protein degradation and (iii) osmosensing and potentially carbon source sensing are predicted. Homologues of the MAP kinases Kss1p, involved in filamentation and invasion as well as Smk1p, involved in spore cell wall assembly were not detected. The MAP kinase cascade assigned to pheromone response and biocontrol comprises the MAPK TMK1, the MAPKK tre35500 and the MAPKKK tre39827. TMK1 represents the H. jecorina homologue of Fus3p (E-value 1e-122) and shares high similarity with Hypocrea virens TMKA (AAN34610) and T. atroviride TMK1 (AAM69918), which are involved in biocontrol $[80,82]$ as well as with the $M$. grisea pathogenicity MAP kinase Pmk1 (AAC49521; [76]). The MAPKK tre 35500 shares highest similarity to $S$. cerevisiae Ste7p (E-value 5e-65) and is related to Glomerella cingularia EMK1 (AAD55386; E-value 2e-178), which is 
required for appressorium formation in this fungus [91]. tre 4945 was assigned to this pathway because of its similarity to Ste11p (E-value 1e-90). However, due to the interaction of Ste11p also with Hog1p and Pbs2p a participation of this factor in osmosensing should be considered. The second MAP kinase cascade consists of TMK2, MKK1 and tre39827. TMK2 is related to S. cerevisiae Slt2p (E-value 1e-122), which is the MAP kinase of the stress response pathway, MKK1 shares high similarity to Mkk1p and tre39827 is the H. jecorina orthologue of Bck1p, which is a target for phosphorylation by protein kinase $\mathrm{C}$ (Hypocrea jecorina orthologue: PKC1). An orthologue corresponding to the protein redundant to Mkk1p, Mkk2p, was not detected in $H$. jecorina. The interactions of Slt $2 \mathrm{p}$ with the 26S proteasome regulatory protein Rpt3p and of Mkk1p with the 26S proteasome regulatory subunit Rpn1p suggest a role for this pathway also in regulation of protein degradation. In this respect it should be considered that MAP kinase pathways themselves can be subject to regulation by ubiquitin mediated degradation [92]. A potential autoregulatory cycle in MAP kinase signaling could thus be worth exploring. The pathway assigned to osmosensing comprises TMK3 (E-value of $1 \mathrm{e}-175$ to Hog1p), tre30518 (E-value of 1e-98 to Pbs2p) and tre29559 (E-value of 1e-140 to Ssk2p). The interactions of the TMK3 orthologue with Sko1, a hydrolase regulating transcription factor and of the tre 29559 orthologue with the CCAAT-binding factor Hap2p, the H. jecorina ortho-

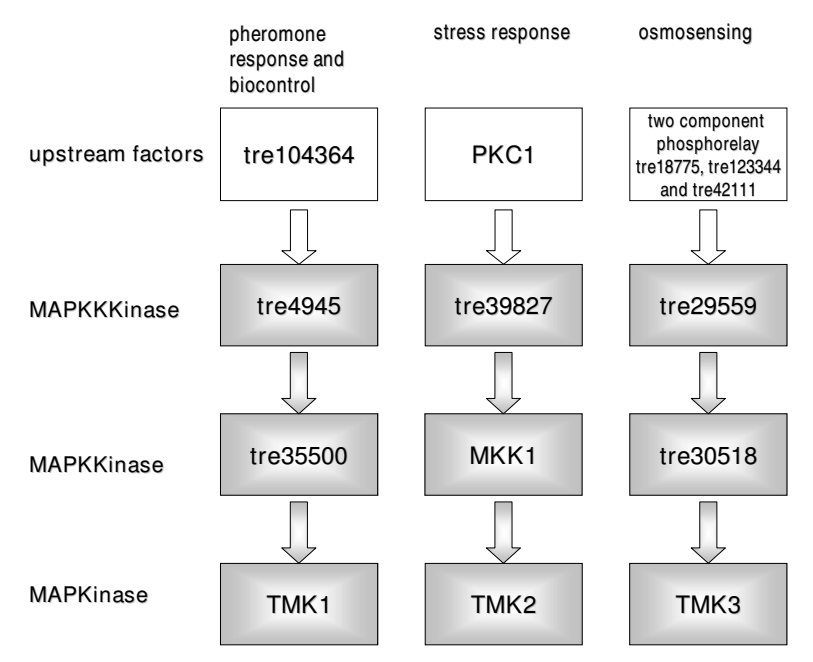

\section{Figure 4}

Model for proposed MAP kinase cascades. Pathways are given as deduced from reported functions and interactions of the respective nearest neighbours in S. cerevisiae and other filamentous ascomycetes. Therefore this model should be considered only a suggestion for further research needed to confirm these pathways. logue of which binds to the cellulase activating element CAE within the cbh2-promotor [93], suggest a role of this pathway also in carbon source signaling. Moreover, the tmk3-transcript was shown to be responsive to light and regulated by ENVOY [13], which - considering the involvement of the N. crassa homologue OS- 2 in circadian rhythmicity [89] - warrants a more detailed analysis of its function in $H$. jecorina.

\section{p2 I activated kinases (PAKs)}

Members of this protein kinase family are able to modulate MAP kinase pathways and can be activated by binding to GTP-bound Rho-like GTPases of the Cdc42/Rac family $[94,95]$. PAKs characteristically comprise a serine/threonine protein kinase domain at the C-terminus and a CRIB (Cdc42/Rac interactive binding)-domain at the $\mathrm{N}$-terminus. The CRIB domain can bind the serine/threonine kinase domain and thereby inhibit its activity. This inhibition can be abolished by binding of a GTP bound Rholike GTPase to the CRIB domain. The best characterized member of this family of kinases, S. cerevisiae Ste20p, is often referred to as MAP4K because of its regulatory impact on the Fus3 MAP kinase pathway. Ste20p is further involved in pheromone response, response to osmotic stress, filamentation and polarized growth and links the pheromone response G-protein beta gamma subunits to downstream signaling components $[96,97]$. Cla4p, the second PAK of S. cerevisiae is involved in budding and cytokinesis [98]. The $H$. jecorina genome comprises homologues of the S. cerevisiae PAKs Ste20p (tre104364) and Cla4p (tre28344). Both tre104364 and tre28344 also contain the characteristic CRIB-domain at the N-terminus.

\section{Germinal center kinases (GCKs)}

Germinal center kinases represent the second group of Ste20-like protein kinases [99]. These kinases are related to the human germinal center kinase (GCK) and are implicated in the regulation of stress activated MAPK signaling pathways. In contrast to the p21 activated kinases, their serine/threonine kinase domain is present at the $\mathrm{N}$ terminus of the protein and is followed by a poorly conserved sequence lacking CRIB or PH domains. These Cterminal sequences may contribute to the autoinhibition of the kinase activity, which can be counteracted by binding of other components. H. jecorina contains one candidate germinal center kinase related to $S$. cerevisiae Sps1p (tre45283) and three candidates related to S. cerevisiae Kic1p (tre30044, tre61703, tre43532). Due to the low conservation within this family, assigning functions to these proteins and confirmation that they indeed are germinal center kinases will only be possible after functional characterization. 


\section{Two component phosphorelay systems}

Two component histidine kinase phosphorelay systems represent conserved signaling pathways employed by both prokaryotes and eukaryotes to adapt to changes in their environment. Components of this system have been characterized from bacteria, slime moulds, plants and fungi, but they were not found in animals. Their functions range from differentiation, chemotaxis, secondary metabolite production and virulence to adaptation to osmotic stress [100]. However, since there are classes of histidine kinases for which a physiological function remains to be identified, this list may still be incomplete. Signaling via two component phosphorelay systems in response to an environmental signal is initiated by ATP-dependent autophosphorylation of the histidine kinase (HK) at a conserved histidine residue. Then this phosphate is transferred to a conserved aspartic acid within a response regulator (RR) domain, which ultimately causes a change in transcription of the respective target gene or regulation of a mitogen-activated protein kinase pathway [101]. Two different types of two component signaling have been described: With the simple histidine kinases the sensor histidine kinase and the regulator receiver are separate proteins, whereas hybrid histidine kinases contain both HK and RR domains on the same protein and generally require additional rounds of phosphorelay through a histidine phosphotransferase ( $\mathrm{HPt}$ ) and another RR protein (Figure 5). In fungi to date only hybrid histidine kinases have been identified and in general they are predominant in eukaryotes, while simple HKs are predominant in prokaryotes.

Although components of phosphorelay systems have been analysed from several organisms, the most comprehensive survey on the mechanism is available from S. cerevisiae: The sole yeast histidine kinase $\operatorname{Sln} 1 \mathrm{p}$ is part of the two component regulatory system Sln $1 \mathrm{p} /$ Ssk $1 \mathrm{p}$ and becomes activated by changes in osmolarity of the extracellular environment. Sln $1 \mathrm{p}$, the signal receiver becomes autophosphorylated at an internal histidine residue. This phosphate is then intramolecularly transferred to an aspartic acid residue and finally to a histidine in the histidine phosphotransferase Ypd1p. Thereafter phosphotransfer occurs to an aspartic residue in the response regulator Ssk1p. This phosphorelay system targets the Ssk2p-Pbs2-Hog1 MAP kinase cascade, which also has an equivalent in $H$. jecorina. As long as $\operatorname{Sin} 1 \mathrm{p}$ is incative, the unphosphorylated Ssk1p can activate the MAP kinase kinase kinase Ssk2p, which can stimulate the Pbs2pHog1p cascade in order to induce glycerol synthesis in the cell. Upon decreased osmolarity, the activation of this MAP kinase cascade is repressed due to activation of Sln1p, which phosphorylates Ssk1p [102].
In $N$. crassa the response regulator protein RRG-1 is involved in control of vegetative cell integrity, hyperosmotic sensitivity, fungicide resistance and protoperithecial development through regulation of the osmosensitivity MAP kinase pathway [87]. RRG-2, the second response regulator protein of $N$. crassa, is involved in oxidative stress response and the histidine phosphotransferase HPT-1 is assumed to negatively regulate a downstream MAP kinase pathway [103]. As for the hybrid histidine kinases, members of class III are among the best studied in filamentous fungi and are implicated mainly in osmosensing, their target being the respective MAP kinase cascade $[104,105]$. In A. nidulans, a recent study showed that at least some of its histidine kinases are both spatially and temporally differentially expressed during the cell cycle [106]. The response regulators of this fungus are involved in stress signaling and asexual sporulation [107].

Genome analysis of $H$. jecorina revealed the presence of ten putative histidine kinases, all of them hybrid HKs (Figure 6) as characterized by the presence of a response regulator receiver domain (IPR001789), a histidine kinase domain (IPR005467) and an ATP binding region (IPR003594). Further domains present in the HKs of $H$. jecorina were GAF-domains (IPR003018), which are often found in phytochromes, a HAMP-region (IPR003660) charakteristic for signaling HKs, PAS domains (IPR000014) implicated in sensing light, oxygen or volt-

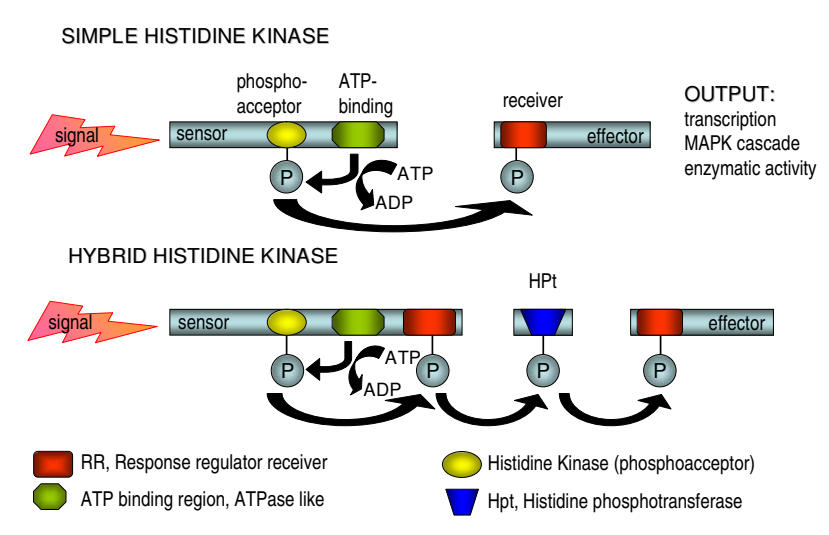

\section{Figure 5}

Schematic representation of two component phosphorelay systems (adapted from [180]). In response to an environmental signal the two component phosphorelay signaling cascade is initiated by ATP-dependent autophosphorylation of the histidine kinase (HK) at a conserved histidine residue. Then this phosphate is transferred to a conserved aspartic acid within a response regulator (RR) domain, which ultimately causes a change in transcription of the respective target gene or regulation of a mitogen-activated protein kinase pathway [ $\mathrm{IOI}]$. 
age and in one case a bacteriophytochrome domain (IPR009219). These various domains allow for the classification of histidine kinases as described in the following.

According to the classification of Catlett et al., [108] the ten histidine kinases of $H$. jecorina belong to nine different classes (Table 4) and only members of classes II and VII, which comprise specialized HKs of C. heterostrophus, $B$. fuckeliana and G. moniliformis, but no orthologues of other fungi, are missing. As the functions of these genes are not known, the significance of their presence or absence remains obscure. Among the classes covered by members from $H$. jecorina are also those which contain closely related sequences from each species analyzed and are thus likely to represent the core HKs of fungi (groups III, V, VI, VIII, IX and X). The distribution of HKs among the groups varies between $N$. crassa and $H$. jecorina. While the Neurospora genome comprises two phytochromes (class VIII) and two members of group XI, $H$. jecorina only has one phytochrome (tre39871) and one member of group IX (tre30271). Interestingly, both groups are characterized by the presence of PAS-domains and hence this might reflect a more elaborate application of ligand- and presumably FAD-mediated signaling in $N$. crassa than in $H$. jecorina. Nevertheless, the finding of a phytochrome indicates that $H$. jecorina is able to sense and respond to the presence of red and far-red light [109]. However, the precise function of the phytochromes in light response of fungi remains to be determined, since deletion of the $N$. crassa phytochrome genes $p h y-1$ and $p h y-2$ did not compromise any known photoresponse [110]. Also in C. heterostrophus phytochrome deletion did not yield a discernible phenotype [108]. On the other hand, studies in A. nidulans revealed that the phytochrome FphA represses sexual development and mycotoxin formation in red light and that it is part of a complex comprising LreA and LreB, the homologues of $N$. crassa WC- 1 and WC-2. Moreover FphA interacts with the light dependent regulator protein VeA [111-113]. H. jecorina possesses two class I HKs (tre28835 and tre32625) in contrast to one in $N$. crassa. Due to the function of the S. cerevisiae class I HK Ssk1p in osmoregulation, a similar function can be assumed in H. jecorina.

Besides the histidine kinases as central components of the phosphorelay, also one histidine phosphotransferase (tre123344; IPR008207) and three response regulator receivers (tre124302, tre44708 and tre31795) were identified, two of which correspond to the $S$. cerevisiae RRs Ssk1p and Skn7p and could consequently have a function in osmosensing or response to oxidative stress, respectively (Table 4). Among them, tre124302 corresponds to the recently characterized $N$. crassa response regulator protein RRG-1 [87] and tre44708 represents the H. jecorina orthologue of RRG-2. tre31795 contains an N-termi- nal serine/threonine protein kinase domain additionally to the response regulator domain and is related to $S$. cerevisiae Rim15p. This kinase acts immediately downstream and under the control of the CAMP-dependent protein kinase. Overexpression of Rim 15 partially induces a starvation response [114].

The presence of hybrid histidine kinases and multistep phosphorelays provides the fungus with a sophisticated means to integrate numerous environmental signals by differential regulation of the HKs and RRs. Since $H$. jecorina, as all other as yet analyzed fungi, only has one histidine phosphotransferase, this protein is likely to have a crucial regulatory function on several output pathways.

\section{Circadian rhythms and light response}

Light is a crucial environmental factor for most living creatures. The presence or absence of light is connected to a plethora of fundamental influences on the life of an organism such as the intensity of harmful UV-light as well as changes in humidity and temperature. Anticipation of and appropriate adaptation to these changes inferred by sunrise or sunset can thus provide a significant evolutionary advantage (for reviews see $[115,116]$ ). In the case of fungi the presence of light also indicates growth over an exposed surface, where the encounter of a potential mating partner can be expected and successful dissemination or sexual development after disposal of spores and conidia is enabled. This might be one rationale behind the often reported effect of light on conidiation of fungi.

Photobiology in $H$. jecorina has only recently received closer attention because of the finding that cellulase gene expression is modulated by light [12]. Nevertheless, there is only limited information available on circadian rhythms and light response at the molecular level in this fungus. A summary on light induced development in Trichoderma species with an emphasis on sporulation has been provided by Betina and Farkas [117]. The main reported responses to illumination described so far are a rapid rise in the intracellular concentration of ATP, paralleled by an increase in the intracellular level of cyclic AMP [118-120], a burst of respiratory activity as indicated by oxygen uptake by dark-grown mycelia of Trichoderma immediately after the onset of illumination [121] and initiation of photoconidiation.

H. jecorina sporulates well both in light and darkness, albeit the amount of spores produced is lower in constant darkness. In Trichoderma viride, the production of conidiation rings depends on the frequency of irradiation and is not subject to circadian rhythm $[117,122]$. A similar phenomenon has been observed in $H$. jecorina: In the absence of light pulses, $H$. jecorina sporulates continuously without detectable formation of conidiation rings both in con- 


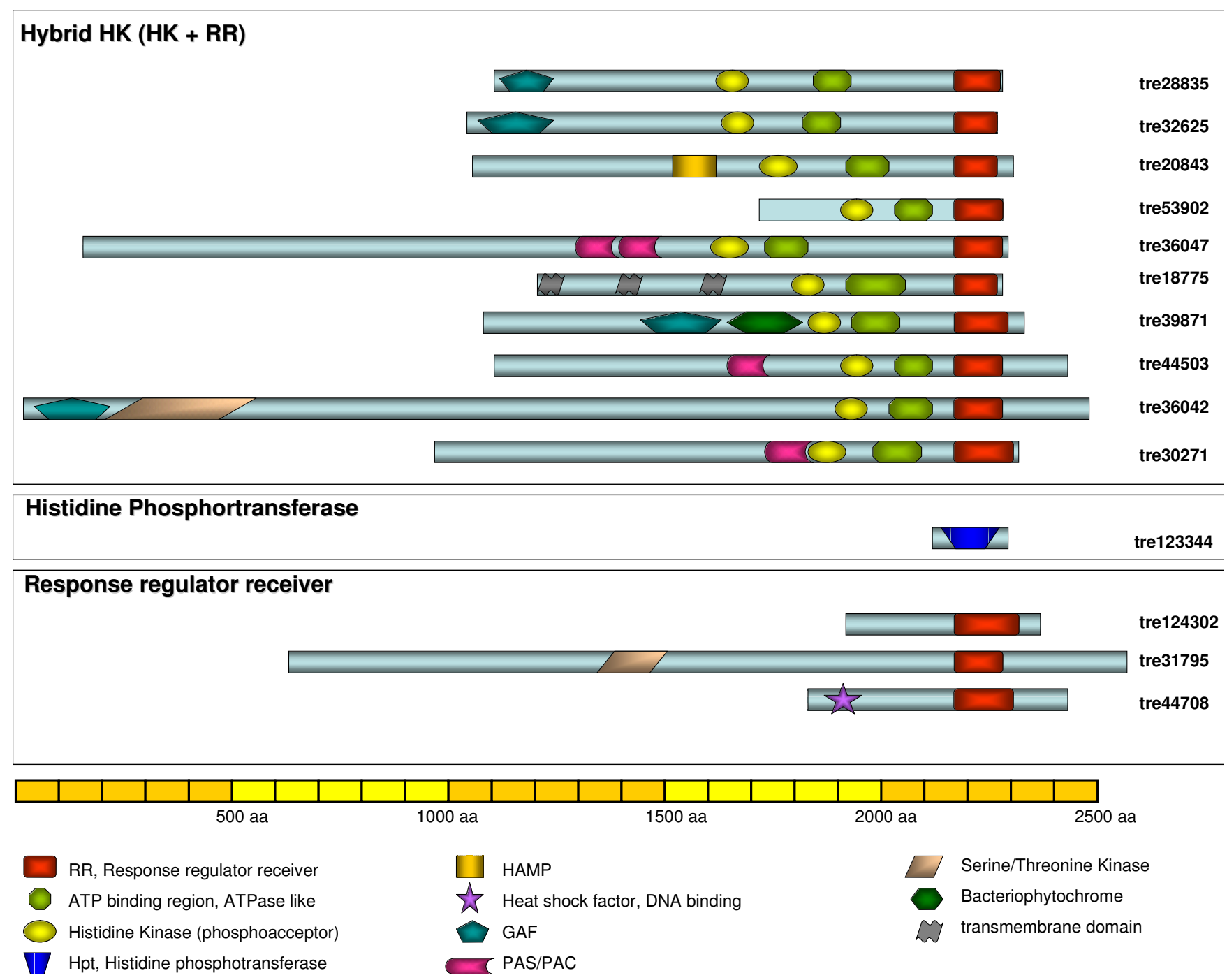

Figure 6

Domain structure of two component phosphorelay histidine kinases and their putative interactors in $\mathbf{H}$. jecorina. Models of the predicted proteins as annotated in the Trichoderma reesei Genome database v2.0 are drawn to scale. Position and significance of the respective domains was determined by InterPro search and NCBI CDD search.

stant light or constant darkness (M. Schmoll, unpublished results).

The central components of the signaling pathways triggering circadian rhythms and light response have been studied extensively in N. crassa (for reviews see [123-125]). The most important input factors for the entrainment of the circadian clock are light and temperature, the blue light photoreceptor WC-1 (white collar-1) being essential for the circadian clock and other light responses and WC2 (white collar-2) representing its partner in the light signaling pathway. Together these proteins form the white collar complex and both components have been shown to be required for all known light responses. This complex binds to the promotor of the clock gene frequency (frq1) and drives its expression. The respective gene product in turn is able to dampen expression of its own transcript by interaction with the white collar complex [124]. Besides these central components also the small LOV/PAS domain blue light sensor VIVID (VVD) plays important roles in light responses and photoentrainment of the clock $[126,127]$. The genome of $H$. jecorina comprises orthologues of N. crassa WC-1 (BLR1, AAV80185, E-value 0.0), WC-2 (BLR2, AAV80186, E-value 1e-118), VVD (ENV1, AY551804, E-value 1e-32) and FRQ (FRQ1, Evalue 0.0$)$. Thus the central components of the clock are available. The homologues of the H. jecorina photoreceptors BLR1 and BLR2 have been studied in the closely related $T$. atroviride and are essential for blue light induced conidiation $[128,129]$, which is dependent on the carbon 
Table 4: Two component phosphorelay systems

\begin{tabular}{|c|c|c|c|c|c|c|c|c|c|c|c|}
\hline $\begin{array}{c}\text { Protein } \\
\text { class }\end{array}$ & protein ID & group & Best hit overall & $\begin{array}{l}\text { Best hit non } \\
\text { Trichoderma }\end{array}$ & S. cerevisiae & S. pombe & $\begin{array}{c}\text { Plant } \\
\text { (Viridiplantae } \\
\text { limited) }\end{array}$ & Neurospora & Aspergillus & Fusarium & Magnaporthe \\
\hline $\begin{array}{l}\text { Histidine } \\
\text { kinase }\end{array}$ & tre 28835 & I & $\begin{array}{c}\text { Gibberella } \\
\text { moniliformis } \\
\text { putative histidine } \\
\text { kinase M27Mp, } \\
0.0,41 \% \\
\text { (AAR30I36.I) } \\
\text { II } 90 \text { aa }\end{array}$ & & None & $\begin{array}{c}\text { hypothetical } \\
\text { protein } \\
\text { SPACI834.08, } \\
6 \mathrm{e}-13,33 \% \\
\text { (CAB75776.I) } \\
\text { 1639 aa }\end{array}$ & $\begin{array}{c}\text { Arabidopsis } \\
\text { thaliana histidine } \\
\text { kinase-like } \\
\text { protein, } 5 \mathrm{e}-13 \\
34 \% \\
\text { (CAC08246.I) } \\
950 \mathrm{aa}\end{array}$ & $\begin{array}{c}\text { Neurospora crassa } \\
\text { putative two } \\
\text { component } \\
\text { histidine kinase } \\
\text { NCU09520, Ie- } \\
99,30 \% \\
\text { (DAA022 I7.I) } \\
1529 \text { aa }\end{array}$ & $\begin{array}{c}\text { Aspergillus } \\
\text { fumigatus sensor } \\
\text { histidine kinase/ } \\
\text { response } \\
\text { regulator, 2e-135, } \\
\text { 31\%(EAL84386.I) } \\
\text { II } 170 \text { aa }\end{array}$ & $\begin{array}{c}\text { Gibberella } \\
\text { moniliformis } \\
\text { putative histidine } \\
\text { kinase M27Mp, } \\
0.0,41 \% \\
\text { (AAR30136.I) } \\
\text { I190 aa }\end{array}$ & $\begin{array}{c}\text { Magnaporthe } \\
\text { grisea } \\
\text { hypothetical } \\
\text { protein } \\
\text { MG02897.4, 2e- } \\
13,31 \% \\
\left(X_{3} 366821.1\right) \\
\text { 833 aa }\end{array}$ \\
\hline $\begin{array}{l}\text { Histidine } \\
\text { kinase }\end{array}$ & tre32625 & I & $\begin{array}{c}\text { Gibberella } \\
\text { moniliformis } \\
\text { putative histidine } \\
\text { kinase M27Mp, } \\
0.0,38 \% \\
\text { (AAR30136.I) } \\
\text { II } 90 \text { aa }\end{array}$ & $\begin{array}{c}\text { Gibberella } \\
\text { moniliformis } \\
\text { putative histidine } \\
\text { kinase M27Mp, } \\
0.0,38 \% \\
\text { (AAR30136.I) } \\
\text { I190 aa }\end{array}$ & $\begin{array}{c}\text { cytoplasmic } \\
\text { response } \\
\text { regulator Ssk } 1 \mathrm{p}, \\
\text { le-13,32\% } \\
(\mathrm{NP} 013106.1) \\
\overline{712 \text { aa }}\end{array}$ & $\begin{array}{c}\text { hypothetical } \\
\text { protein } \\
\text { SPACI 1834.08, } \\
\text { 2e-15, 36\% } \\
\text { (NP 594687.I) } \\
\text { I639 aa }\end{array}$ & $\begin{array}{c}\text { Arabidopsis } \\
\text { thaliana histidine } \\
\text { kinase-like } \\
\text { protein, } 5 \mathrm{e}-\mathrm{I} 2 \\
32 \% \\
(\mathrm{CAC08246.I)} \\
950 \mathrm{aa}\end{array}$ & $\begin{array}{c}\text { Neurospora crassa } \\
\text { hypothetical } \\
\text { protein } \\
\text { NCU09520.I, 5e- } \\
89,29 \% \\
\text { (DAA022I7.I) } \\
\text { I529 aa }\end{array}$ & $\begin{array}{c}\text { Aspergillus nidulans } \\
\text { histidine kinase } \\
\text { G7, I e-II17,29\% } \\
\text { (AAQ | } 19475.1 \text { ) } \\
\text { I282 aa }\end{array}$ & $\begin{array}{c}\text { Gibberella } \\
\text { moniliformis } \\
\text { putative histidine } \\
\text { kinase M27Mp, } \\
0.0,38 \% \\
\text { (AAR30136.I) } \\
\text { II } 90 \text { aa }\end{array}$ & $\begin{array}{c}\text { Magnaporthe } \\
\text { grisea } \\
\text { hypothetical } \\
\text { protein } \\
\text { MG02897.4, 3e- } \\
12,31 \% \\
\left(X_{1} 366821.1\right) \\
833 \text { aa }\end{array}$ \\
\hline $\begin{array}{l}\text { Histidine } \\
\text { kinase }\end{array}$ & tre20843 & III & $\begin{array}{c}\text { Fusarium solani } \\
\text { histidine kinase } \\
\text { FIK, 0.0,89\% } \\
\text { (AAD0991..) } \\
\text { I283 aa }\end{array}$ & $\begin{array}{c}\text { Fusarium solani } \\
\text { histidine kinase } \\
\text { FIK, 0.0, 89\% } \\
\text { (AAD0941.I) } \\
\text { I283 aa }\end{array}$ & $\begin{array}{c}\text { nuclear response } \\
\text { regulator and } \\
\text { transcription } \\
\text { factor Skn7p, Ie- } \\
14,32 \% \\
\left(N_{1} 012076.1\right) \\
622 \text { aa }\end{array}$ & None & None & $\begin{array}{c}\text { Neurospora crassa } \\
\text { Os-Ip, 0.0, 80\% } \\
\text { (AAB01979.I) } \\
\text { I298 aa, } \\
\text { corresponding to } \\
\text { NCU02815.I }\end{array}$ & $\begin{array}{c}\text { Aspergillus } \\
\text { fumigatus two- } \\
\text { component } \\
\text { osmosensing } \\
\text { histidine kinase } \\
\text { Bos I, 0.0, 66\% } \\
\text { (EAL8745I.I) } \\
\text { I377 aa }\end{array}$ & $\begin{array}{c}\text { Fusarium solani } \\
\text { histidine kinase } \\
\text { FIK, 0.0, 89\% } \\
\text { (AAD0991.I) } \\
\text { I283 aa }\end{array}$ & $\begin{array}{c}\text { Magnaporthe } \\
\text { grisea histidine } \\
\text { kinase, 0.0,79\% } \\
\text { (BAB40947.I) } \\
\text { I } 307 \text { aa }\end{array}$ \\
\hline $\begin{array}{l}\text { Histidine } \\
\text { kinase }\end{array}$ & tre53902 & IV & $\begin{array}{c}\text { Neurospora crassa } \\
\text { related to } \\
\text { histidine kinase } \\
\text { tcsA protein, 0.0, } \\
62 \% \\
(\text { CAD7I } 062.1) \\
922 \text { aa }\end{array}$ & $\begin{array}{c}\text { Neurospora crassa } \\
\text { related to } \\
\text { histidine kinase } \\
\text { tcsA protein, 0.0, } \\
62 \% \\
(\text { CAD7I062.1) } \\
922 \text { aa }\end{array}$ & None & None & $\begin{array}{c}\text { Oryza sativa } \\
\text { putative sensor } \\
\text { kinase PK4, le- } \\
59,36 \% \\
\text { (AAP07255.1) } \\
653 \text { aa }\end{array}$ & $\begin{array}{c}\text { Neurospora crassa } \\
\text { related to } \\
\text { histidine kinase } \\
\text { tcsA protein, 0.0, } \\
62 \% \\
(\text { CAD71062.1) } \\
922 \text { aa }\end{array}$ & $\begin{array}{c}\text { Aspergillus } \\
\text { parasiticus } \\
\text { histidine kinase } \\
7 \mathrm{e}-163,52 \% \\
\text { (AAR92365. } \\
708 \text { aa }\end{array}$ & $\begin{array}{c}\text { Gibberella zeae } \\
\text { hypothetical } \\
\text { protein } \\
\text { FG05866.I, I e-6I, } \\
35 \% \\
\text { (EAA7564I.I) } \\
2544 \text { aa }\end{array}$ & $\begin{array}{c}\text { Magnaporthe } \\
\text { grisea } \\
\text { hypothetical } \\
\text { protein } \\
\text { MG01342.4, 6e- } \\
55,33 \% \\
\text { (EAA55691.I) } \\
\text { | } 388 \text { aa }\end{array}$ \\
\hline $\begin{array}{l}\text { Histidine } \\
\text { kinase }\end{array}$ & tre36047 & $\mathbf{v}$ & $\begin{array}{c}\text { Gibberella } \\
\text { moniliformis } \\
\text { putative histidine } \\
\text { kinase HHK2p, } \\
0.0,62 \% \\
\text { (AAR30137.I) } \\
2072 \text { aa }\end{array}$ & $\begin{array}{c}\text { Gibberella } \\
\text { moniliformis } \\
\text { putative histidine } \\
\text { kinase HHK2p, } \\
0.0,62 \% \\
\text { (AAR30137.I) } \\
2072 \text { aa }\end{array}$ & None & $\begin{array}{c}\text { hypothetical } \\
\text { protein } \\
\text { SPACI834.08, } \\
\text { Ie-76, 49\% } \\
\text { (CAB75776.I) } \\
\text { I639 aa }\end{array}$ & $\begin{array}{c}\text { Oryza sativa } \\
\text { putative sensor } \\
\text { kinase PK4, 4e- } \\
41 \\
\text { (AAQ07255.I) }\end{array}$ & $\begin{array}{c}\text { Neurospora crassa } \\
\text { related to two } \\
\text { component } \\
\text { histidine kinase } \\
\text { chk-1, 0.0, 57\% } \\
\text { (CAD70476.1) } \\
2177 \text { aa }\end{array}$ & $\begin{array}{c}\text { Aspergillus nidulans } \\
\text { hypothetical } \\
\text { protein } \\
\text { AN3101.2, 0.0, } \\
35 \% \\
(X P \text { 660705.1) } \\
\text { 1879 aa }\end{array}$ & $\begin{array}{c}\text { Gibberella } \\
\text { moniliformis } \\
\text { putative histidine } \\
\text { kinase HHK2p, } \\
0.0,62 \% \\
\text { (AAR30137.I) } \\
2072 \text { aa }\end{array}$ & $\begin{array}{c}\text { Magnaporthe } \\
\text { grisea histidine } \\
\text { kinase, 4e-47, } \\
44 \% \\
\left(X_{1363718.1)}\right. \\
\text { 1307 aa }\end{array}$ \\
\hline $\begin{array}{l}\text { Histidine } \\
\text { kinase }\end{array}$ & tre $\mid 8775$ & VI & $\begin{array}{c}\text { Neurospora crassa } \\
\text { related to protein } \\
\text { histidine kinase, } \\
0.0,61 \% \\
\text { (CAD } 37055.1) \\
\text { 1266 aa }\end{array}$ & $\begin{array}{c}\text { Neurospora crassa } \\
\text { related to protein } \\
\text { histidine kinase, } \\
0.0,61 \% \\
\text { (CAD } 37055.1) \\
\text { 1266 aa }\end{array}$ & 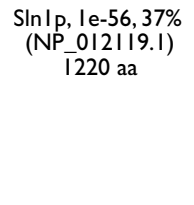 & None & $\begin{array}{c}\text { Oryza sativa } \\
\text { putative histidine } \\
\text { kinase, 4e-36, } \\
27 \% \\
\left(X_{2} 463649.1\right) \\
\text { 1023 aa }\end{array}$ & $\begin{array}{c}\text { Neurospora crassa } \\
\text { related to protein } \\
\text { histidine kinase, } \\
0.0,61 \% \\
\text { (CAD } 37055.1) \\
\text { 1266 aa }\end{array}$ & $\begin{array}{c}\text { Emericella nidulans } \\
\text { Two-component } \\
\text { system protein B } \\
\text { precursor NHKI, } \\
0.0,49 \% \\
\text { (Q9P4U6) I070 } \\
\text { aa }\end{array}$ & $\begin{array}{c}\text { Gibberella } \\
\text { moniliformis } \\
\text { putative histidine } \\
\text { kinase HHK5 } 5 \text {, } \\
0.0,61 \% \\
\text { (AAR30125.1) } \\
\text { II50 aa }\end{array}$ & $\begin{array}{c}\text { Magnaporthe } \\
\text { grisea } \\
\text { hypothetical } \\
\text { protein } \\
\text { MG07312.4 0.0, } \\
57 \% \% \\
\left(X_{3} 367387.1\right) \\
\text { |206 aa }\end{array}$ \\
\hline $\begin{array}{l}\text { Histidine } \\
\text { kinase }\end{array}$ & tre3987I & VIII & $\begin{array}{c}\text { Gibberella } \\
\text { moniliformis } \\
\text { putative } \\
\text { phytochrome-like } \\
\text { histidine kinase } \\
\text { PHYIp, } 0.0,65 \% \\
\text { (AAR330124.I) } \\
\text { I469 aa }\end{array}$ & $\begin{array}{c}\text { Gibberella } \\
\text { moniliformis } \\
\text { putative } \\
\text { phytochrome-like } \\
\text { histidine kinase } \\
\text { PHY Ip, } 0.0,65 \% \\
\text { (AAR30124.I) } \\
\text { I } 469 \text { aa }\end{array}$ & None & None & $\begin{array}{c}\text { Sorghum } \\
\text { propinquum } \\
\text { phytochrome C, } \\
\text { Ie-29, 25\% } \\
\text { (AAR33032.I) } \\
\text { II35 aa }\end{array}$ & $\begin{array}{c}\text { Neurospora crassa } \\
\text { phytochrome-I, } \\
0.0,62 \% \\
\text { (AAZ57422.I) } \\
\text { I536 aa }\end{array}$ & $\begin{array}{c}\text { Aspergillus nidulans } \\
\text { phytochrome, } 0.0 \text {, } \\
50 \% \text { (CA130283.I) } \\
\text { I } 280 \text { aa }\end{array}$ & $\begin{array}{c}\text { Gibberella } \\
\text { moniliformis } \\
\text { putative } \\
\text { phytochrome-like } \\
\text { histidine kinase } \\
\text { PHY Ip, } 0.0,65 \% \\
\text { (AAR } 30124.1) \\
\text { I } 469 \text { aa }\end{array}$ & $\begin{array}{c}\text { Magnaporthe } \\
\text { grisea } \\
\text { hypothetical } \\
\text { protein } \\
\text { MGI342.4, 3e- } \\
34,27 \% \\
\left(X_{1} 363416.1\right) \\
\text { 188 aa }\end{array}$ \\
\hline
\end{tabular}


Table 4: Two component phosphorelay systems (Continued)

\begin{tabular}{|c|c|c|c|c|c|c|c|c|c|c|c|}
\hline $\begin{array}{l}\text { Histidine } \\
\text { kinase }\end{array}$ & tre 44503 & IX & $\begin{array}{c}\text { Gibberella } \\
\text { moniliformis } \\
\text { putative histidine } \\
\text { kinase HHK6p, } \\
0.0,67 \% \\
\text { (AAR30123.1) } \\
1369 \text { aa }\end{array}$ & $\begin{array}{c}\text { Gibberella } \\
\text { moniliformis } \\
\text { putative histidine } \\
\text { kinase HHK6p, } \\
0.0,67 \% \\
\text { (AAR30123.I) } \\
\text { 1369 aa }\end{array}$ & None & $\begin{array}{c}\text { hypothetical } \\
\text { protein } \\
\text { SPACI834.08, } \\
\text { 6e-50, 30\% } \\
\text { (CAB75776.1) } \\
\text { 1639 aa }\end{array}$ & $\begin{array}{c}\text { Oryza sativa } \\
\text { putative sensor } \\
\text { histidine kinase } \\
\text { PK4,4e-4I, 40\% } \\
\text { (AAQ07255.I) } \\
653 \text { aa }\end{array}$ & $\begin{array}{c}\text { Neurospora crassa } \\
\text { hypothetical } \\
\text { protein } \\
\text { NCU2 } 2057.1,0.0, \\
52 \% \text { (XP } 964013) \\
1319 \text { aa }\end{array}$ & $\begin{array}{c}\text { Aspergillus } \\
\text { fumigatus sensor } \\
\text { histidine kinase/ } \\
\text { response } \\
\text { regulator, } \\
\text { putative, } 3 \mathrm{e}-45, \\
45 \% \text { (EAL92328. } \\
2333 \text { aa }\end{array}$ & $\begin{array}{c}\text { Gibberella } \\
\text { moniliformis } \\
\text { putative histidine } \\
\text { kinase HHK6p, } \\
0.0,67 \% \\
\text { (AAR30I23.I) } \\
\text { I369 aa }\end{array}$ & $\begin{array}{c}\text { Magnaporthe } \\
\text { grisea } \\
\text { hypothetical } \\
\text { protein } \\
\text { MG01342.4, 0.0, } \\
54 \% \\
\text { (EAA5569I.I) } \\
\text { I } 388 \text { aa }\end{array}$ \\
\hline $\begin{array}{l}\text { Histidine } \\
\text { kinase }\end{array}$ & tre36042 & $\mathbf{x}$ & $\begin{array}{c}\text { Gibberella } \\
\text { moniliformis } \\
\text { putative histidine } \\
\text { kinase HHKIP, } \\
0.0,71 \% \\
\text { (AAR30I22.1) } \\
2362 \text { aa }\end{array}$ & $\begin{array}{c}\text { Gibberella } \\
\text { moniliformis } \\
\text { putative histidine } \\
\text { kinase HHKIp, } \\
0.0,71 \% \\
\text { (AAR30I22.I) } \\
2362 \text { aa }\end{array}$ & None & None & $\begin{array}{c}\text { Oryza sativa } \\
\text { putative sensor } \\
\text { kinase PK4, 3e- } \\
61,36 \% \\
\text { (AAP07255.I) } \\
653 \text { aa. }\end{array}$ & $\begin{array}{c}\text { Neurospora crassa } \\
\text { hypothetical } \\
\text { protein, } 0.0,63 \% \\
\left(X P_{\overline{2} 376} 282.1\right) \\
\text { aa }\end{array}$ & $\begin{array}{c}\text { Aspergillus } \\
\text { fumigatus sensor } \\
\text { histidine kinase/ } \\
\text { response } \\
\text { regulator, } 0.0, \\
42 \% \text { (EAL92328.I) } \\
2333 \text { aa }\end{array}$ & $\begin{array}{c}\text { Gibberella } \\
\text { moniliformis } \\
\text { putative histidine } \\
\text { kinase HHKIIp, } \\
0.0,71 \% \\
\text { (AAR30122.I) } \\
2362 \text { aa }\end{array}$ & $\begin{array}{c}\text { Magnaporthe } \\
\text { grisea } \\
\text { hypothetical } \\
\text { protein } \\
\text { MG06696.4, 0.0, } \\
59 \% \\
\left(X^{3} 370199.1\right) \\
2580 \text { aa }\end{array}$ \\
\hline $\begin{array}{l}\text { Histidine } \\
\text { kinase }\end{array}$ & tre3027I & $\mathbf{X I}$ & $\begin{array}{c}\text { Gibberella zeae } \\
\text { hypothetical } \\
\text { protein } \\
\text { FG00856.I, 0.0, } \\
66 \% \\
\text { (EAA70449.I) } \\
\text { I52I aa }\end{array}$ & $\begin{array}{c}\text { Gibberella zeae } \\
\text { hypothetical } \\
\text { protein } \\
\text { FG00856.I, 0.0, } \\
66 \% \\
\text { (EAA70449.I) } \\
\text { I52I aa }\end{array}$ & None & $\begin{array}{c}\text { hypothetical } \\
\text { protein } \\
\text { SPACI 834.08, } \\
3 \mathrm{e}-20 \\
\text { (CAB75776.1) } \\
\text { 1639 aa }\end{array}$ & $\begin{array}{c}\text { Arabidopsis } \\
\text { thaliana } \\
\text { cytokinin } \\
\text { independent 2, } \\
4 \mathrm{e}-17 \\
\text { (AAZ98829.1) }\end{array}$ & 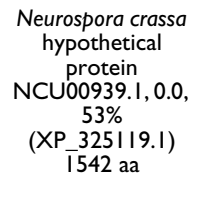 & $\begin{array}{c}\text { Aspergillus nidulans } \\
\text { histidine kinase } \\
\text { G2,7e-79, 32\% } \\
\text { (AAQ19474.I) } \\
659 \text { aa }\end{array}$ & $\begin{array}{c}\text { Gibberella zeae } \\
\text { hypothetical } \\
\text { protein } \\
\text { FG00856.I, 0.0, } \\
66 \% \\
\text { (EAA70449.1) } \\
\text { I52I aa }\end{array}$ & $\begin{array}{c}\text { Magnaporthe } \\
\text { grisea } \\
\text { hypothetical } \\
\text { protein } \\
\text { MG01227.4, } \\
5.0, \\
(X)^{363301.1)} \\
1586 \text { aa }\end{array}$ \\
\hline $\begin{array}{l}\text { Response } \\
\text { regulator }\end{array}$ & tre 124302 & $\mathbf{R R}$ & $\begin{array}{c}\text { Gibberella zeae } \\
\text { hypothetical } \\
\text { protein } \\
\text { FG08948.I, 3e- } \\
100,52 \% \\
\text { (EAA70828.I) } \\
868 \text { aa }\end{array}$ & $\begin{array}{c}\text { Gibberella zeae } \\
\text { hypothetical } \\
\text { protein } \\
\text { FG08948.I, 3e- } \\
100,52 \% \\
\text { (EAA70828.I) } \\
868 \text { aa }\end{array}$ & $\begin{array}{c}\text { Ssklp, 4e-4l, } \\
43 \% \\
\left(\mathrm{NP}_{-013106.1)} 712 \text { aа }\right.\end{array}$ & $\begin{array}{l}\text { Mcs4, 3e-50, } \\
58 \% \text { (P87323) } \\
522 \text { aa }\end{array}$ & $\begin{array}{c}\text { Arabidopsis } \\
\text { thaliana } \\
\text { cytokinin } \\
\text { independent 2, } \\
\text { Ie-11, 31\% } \\
\text { (AAZ98829.1) } \\
922 \text { aa }\end{array}$ & $\begin{array}{c}\text { Neurospora crassa } \\
\text { hypothetical } \\
\text { protein, 4e-90, } \\
45 \% \\
\text { (XP_329085.I) } \\
\text { III4 aa }\end{array}$ & $\begin{array}{c}\text { Aspergillus nidulans } \\
\text { hypothetical } \\
\text { protein } \\
\text { AN7697.2, 5e-67, } \\
62 \% \\
\left(X P \_680966.1\right) \\
838 \text { aa }\end{array}$ & $\begin{array}{c}\text { Gibberella zeae } \\
\text { hypothetical } \\
\text { protein } \\
\text { FG08948.I, 3e- } \\
100,52 \% \\
\text { (EAA70828.I) } \\
868 \text { aa }\end{array}$ & $\begin{array}{c}\text { Magnaporthe } \\
\text { grisea } \\
\text { hypothetical } \\
\text { protein } \\
\text { MG02897.4, } \\
78 \text { e- } \\
\left(X_{3} 366821.1\right) \\
833 \text { aa }\end{array}$ \\
\hline $\begin{array}{l}\text { Response } \\
\text { regulator }\end{array}$ & tre 44708 & $\mathbf{R R}$ & $\begin{array}{c}\text { Gibberella zeae } \\
\text { hypothetical } \\
\text { protein } \\
\text { FG06359.1, 0.0, } \\
61 \% \\
\text { (EAA73807.1) } \\
587 \text { aa }\end{array}$ & $\begin{array}{c}\text { Gibberella zeae } \\
\text { hypothetical } \\
\text { protein } \\
\text { FG06359.1, 0.0, } \\
61 \% \\
\text { (EAA73807.1) } \\
587 \mathrm{aa}\end{array}$ & $\begin{array}{c}\text { Skn7p, le-2l, } \\
36 \% \text { (P38889) } \\
622 \text { aa }\end{array}$ & $\begin{array}{c}\text { Pombe } \\
\text { response } \\
\text { regulator Prrl, } \\
2 \mathrm{e}-53,30 \% \\
(\mathrm{O} \mid 4283) 539 \\
\text { aa }\end{array}$ & $\begin{array}{c}\text { Arabidopsis } \\
\text { thaliana heat } \\
\text { shock factor 6, } \\
4 \mathrm{e}-14,39 \% \\
\text { (Q9SCW4) } 299 \\
\text { aa }\end{array}$ & $\begin{array}{c}\text { Neurospora crassa } \\
\text { hypothetical } \\
\text { protein, 3e-80, } \\
42 \% \\
\left(X_{-3} 331 \text { I } 89.1\right) \\
555 \text { aa }\end{array}$ & $\begin{array}{c}\text { Aspergillus nidulans } \\
\text { hypothetical } \\
\text { protein } \\
\text { AN3688.2, 4e-82, } \\
39 \% \\
\left(X_{3} 661292.1\right) \\
475 \text { aa }\end{array}$ & $\begin{array}{c}\text { Gibberella zeae } \\
\text { hypothetical } \\
\text { protein } \\
\text { FG06359.I, } 0.0 \\
61 \% \\
\text { (EAA73807.1) } \\
587 \mathrm{aa}\end{array}$ & $\begin{array}{c}\text { Magnaporthe } \\
\text { grisea } \\
\text { hypothetical } \\
\text { protein } \\
\text { MG03516.4, le- } \\
83,43 \% \\
\left(X P^{360973.1)}\right. \\
688 \text { aa }\end{array}$ \\
\hline $\begin{array}{l}\text { Response } \\
\text { regulator }\end{array}$ & tre31795 & $\mathbf{R R}$ & $\begin{array}{c}\text { Gibberella zeae } \\
\text { putative response } \\
\text { regulator receiver } \\
\text { RIMI5p, } 0.0,72 \% \\
\text { (AAR30133.I) } \\
1916 \text { aa }\end{array}$ & $\begin{array}{c}\text { Gibberella zeae } \\
\text { putative response } \\
\text { regulator receiver } \\
\text { RIMI15p, 0.0,72\% } \\
\text { (AAR30133.1) } \\
1916 \text { aa }\end{array}$ & 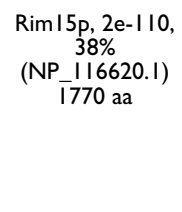 & $\begin{array}{c}\text { cekl, 5e-119, } \\
43 \% \\
(\text { CAB40178.1) } \\
\text { 1338 aa }\end{array}$ & $\begin{array}{c}\text { Arabidopsis } \\
\text { thaliana IRE } \\
\text { homolog, 2e-47, } \\
61 \% \\
\text { (BAB02708.I) } \\
\text { I398 aa }\end{array}$ & $\begin{array}{c}\text { Neurospora crassa } \\
\text { hypothetical } \\
\text { protein } 0.0,62 \% \\
\left(\text { XP_327664.1) }_{1943 \text { aa }}\right.\end{array}$ & $\begin{array}{c}\text { Aspergillus nidulans } \\
\text { hypothetical } \\
\text { protein } \\
\text { AN7572.2, 0.0, } \\
54 \% \\
(X P \quad 680841.1) \\
2104 \text { aa }\end{array}$ & $\begin{array}{c}\text { Gibberella zeae } \\
\text { putative response } \\
\text { regulator receiver } \\
\text { RIMI15p, 0.0,72\% } \\
\text { (AAR30133.1) } \\
1916 \text { aa }\end{array}$ & $\begin{array}{c}\text { Magnaporthe } \\
\text { grisea } \\
\text { hypothetical } \\
\text { protein } \\
\text { MG00345.4, 0.0, } \\
64 \% \text {, } \\
\text { (XP_368899.1) } \\
\text { 1952 aa }\end{array}$ \\
\hline $\begin{array}{l}\text { Histidine } \\
\text { phosphotran } \\
\text { sferase }\end{array}$ & trel 23344 & HPT & $\begin{array}{c}\text { Gibberella zeae } \\
\text { putative histidine } \\
\text { phosphotransfera } \\
\text { se HPTIp, Ie-44, } \\
73 \% \\
\text { (AAR30I I8.I) } \\
\text { I43 aa }\end{array}$ & $\begin{array}{c}\text { Gibberella zeae } \\
\text { putative histidine } \\
\text { phosphotransfera } \\
\text { se HPTIp, Ie-44, } \\
73 \% \\
\text { (AAR30I I8.I) } \\
\text { I43 aa }\end{array}$ & $\begin{array}{c}\text { Phosphorelay } \\
\text { intermediate } \\
\text { protein Ypdlp, } \\
\text { le-10, 45\% } \\
\left(N_{1} 01006.1\right) \\
167 \text { aa }\end{array}$ & $\begin{array}{c}\text { Multistep } \\
\text { phosphorelay } \\
\text { regulator I } \\
\text { MPRI, 2e-24, } \\
47 \% \text { (O9432I) } \\
295 \text { aa }\end{array}$ & $\begin{array}{c}\text { Arabidopsis } \\
\text { thaliana Ahpl, } \\
\text { 4e-5, 24\% } \\
\text { (BAA36335.I) } \\
\text { 154 aa }\end{array}$ & $\begin{array}{c}\text { Neurospora crassa } \\
\text { hypothetical } \\
\text { protein le-24, } \\
52 \% \\
\text { (XP_327928.I) } \\
\text { 145 aa }\end{array}$ & $\begin{array}{c}\text { Aspergillus } \\
\text { fumigatus histidine } \\
\text { containing } \\
\text { phosphotransmitt } \\
\text { er protein, 8e-31, } \\
58 \% \text { (EAL89760.I) } \\
\text { I9I aa }\end{array}$ & $\begin{array}{c}\text { Gibberella zeae } \\
\text { putative histidine } \\
\text { phospho- } \\
\text { transferase } \\
\text { HPT Ip, Ie-44, } \\
73 \% \\
\text { (AAR30I } \\
\text { I43 aa }\end{array}$ & $\begin{array}{c}\text { Magnaporthe } \\
\text { grisea } \\
\text { hypothetical } \\
\text { protein } \\
\text { MG07173.4, 8e- } \\
31,56 \% \\
\left(X P_{-367248.1)}\right. \\
\text { 135 aa }\end{array}$ \\
\hline
\end{tabular}


source [63]. However, it is important to note that in $T$. atroviride the env1-transcript could not be detected and the genomic sequence indicates that functional expression of this important light regulatory gene might be perturbed [13].

ENVOY (ENV1) represents the first signal transduction factor investigated in $H$. jecorina and was shown to be involved both in light response as well as in regulation of cellulase gene expression [12]. In addition, also darkrelated functions as well as both positive and negative regulation of light-responsive genes by ENVOY has been reported [13]. Besides the PAS domain proteins described so far (see also section Two component phosphorelay systems), no additional PAS-domain proteins were identified.

Further N. crassa clock-associated proteins with orthologues found in $H$. jecorina include the E3-ubiquitin ligase FWD-1 (tre30183), which targets FRQ for degradation via the $26 \mathrm{~S}$ proteasome and the light inducible BLI-3 (tre42044). Also three potential class I photolyases were found, one of them representing the homologue of PHR1, which is rapidly (auto-) regulated by blue light in Trichoderma harzianum [130-132]. tre59726 shares considerable similarity with DASH-type cryptochromes from other organisms and is therefore likely to represent the H. jecorina homologue of the Drosophila melanogaster blue light dependent regulator of the circadian feedback loop CRY1 [133] (Table 5). Both PHR1 and tre59726 share high similarities with proteins in N. crassa, other fungi and numerous bacteria. In contrast, tre77473 shows E-values below 1 e-95 to proteins in higher eukaryotes, especially the 6-4 photolyases of Danio rerio and Xenopus laevis, and uncharacterized proteins of several filamentous fungi, but seems to have no homologue in N. crassa.

Besides the casein kinase I HHP1, the N. crassa homologue of which is a homologue of D. melanogaster DOUBLETIME and involved in phosphorylation of FRQ [134], two further candidate casein kinase I proteins have been detected (tre30360 and tre12219). One of them (tre12219) shows highest similarity to a vertebrate casein kinase and seems to have no corresponding homologue in N. crassa, since the best hit again was HHP1 (Table 6). This protein is also highly similar to D. melanogaster DOUBLETIME and could thus indicate an expansion of this group in $H$. jecorina. In contrast to $N$. crassa for which a crucial role of casein kinase II in phosphorylation of FRQ has been reported, $H$. jecorina not only possesses two casein kinase II beta (regulatory) subunits (CKB1 and CKB2) but also two casein kinase II alpha (catalytic) subunits (KC2A and tre38035). tre38035 has in most cases the same homologues as $\mathrm{KC} 2 \mathrm{~A}$, but the best hit is a casein kinase II of Coccidioides imitis. Hence also in this group of casein kinases an expansion may have taken place. A further putative kinase involved in phosphorylation of FRQ, the $N$. crassa calcium/calmodulin protein kinase CAMK has two orthologues in $H$. jecorina: tre44095 and tre18772. Consequently, these apparent expansions in proteins involved in phosphorylation and thus regulation of FRQ suggest that a more sophisticated regulation of the regulatory cycles in which this protein participates may occur. Characterization of FRQ in H. jecorina will elucidate whether this presumably more complex regulation is reflected in a broader spectrum of output pathways. Moreover a glycogen synthase kinase 3 homologue (GSK3) related to D. melanogaster SHAGGY, which is involved in phosphorylation of the central oscillator component TIM [133] was detected. Also a putative homologue of TIM (TIMELESS) is available in H. jecorina (tre53569).

Interestingly, although no responses to red light have been reported for $H$. jecorina so far, its genome comprises a reading frame related to $A$. nidulans VELVET and one candidate phytochrome like histidine kinase (tre39871). Despite the fact that VELVET has initially been reported for its involvement in red-light initiated conidiation in $A$. nidulans $[135,136]$, recently functions exceeding developmental regulation, namely repression of penicillin biosynthesis in this fungus [137] have been shown. Given the lack of known red light responses, functions beyond regulation of development are also conceivable for tre39871.

It is intriguing that despite the presence of homologues to the major determinants of circadian rhythmicity known from other organisms, no such rhythmicity is obvious in $H$. jecorina, at least with respect to the formation of conidial rings in the absence of light pulses. Nevertheless, devoid of molecular data on potential rhythmic expression of at least a few genes, it is still possible that a circadian rhythm is operative, but that the output of the related signaling pathway is disconnected from conidiation. In this respect it is also interesting that $H$. jecorina only has one of the three best studied output genes of circadian rhythms described in $N$. crassa $[138,139]$ : While the geranylgeranyl pyrophosphate synthetase al-3, which is involved in carotenoid biosynthesis, has a highly similar homologue in H. jecorina (tre14246), no homologues to al-1 and al-2 have been detected, which is a further hint as to the presence of different targets of the output pathways of circadian rhythmicity in N. crassa and H. jecorina. On the other hand, both for $H$. jecorina as well as for the closely related $H$. atroviridis it has been shown that numerous genes are regulated by light, which thus could be clock components $[13,140]$.

\section{Calcium signaling}

Calcium plays an important role in intracellular signaling processes in eukaryotic cells [141,142]. The respective sig- 
Table 5: Putative photolyases and cryptochromes.

\begin{tabular}{|c|c|c|c|c|c|c|c|c|c|c|}
\hline Protein class & $\begin{array}{l}\text { protein } \\
\text { ID }\end{array}$ & Best hit overall & Drosophila & Animal & $\begin{array}{c}\text { Plant } \\
\text { (Viridiplantae } \\
\text { limited) }\end{array}$ & Neurospora & Aspergillus & Fusarium & $\begin{array}{l}\text { Magnaporthe } \\
\text { grisea }\end{array}$ & $\begin{array}{l}\text { Ustilago } \\
\text { maydis }\end{array}$ \\
\hline $\begin{array}{c}\text { DNA } \\
\text { photolyase }\end{array}$ & tre77473 & $\begin{array}{c}\text { Gibberella zeae } \\
\text { hypothetical } \\
\text { proteinFG06765. } \\
\text { I, 0.0,71\% } \\
(\text { XP_38694I.I) }\end{array}$ & $\begin{array}{c}\text { REII660p (phr6- } \\
\text { 4), 3e-95, 40\% } \\
\text { (AAL90322.I) }\end{array}$ & $\begin{array}{c}\text { Danio rerio } \\
\text { Cry5, } 2 \mathrm{e}-102, \\
39 \% \\
\text { (AAH44204.I) }\end{array}$ & $\begin{array}{c}\text { Arabidopsis } \\
\text { thaliana UVR3 } \\
\text { (UV repair } \\
\text { defective 4), } \\
2 \mathrm{e}-92,36 \% \\
\text { (NP566520.I) }\end{array}$ & $\begin{array}{c}\text { hypothetical } \\
\text { protein } \\
\text { NCU00582.I } \\
\text { (XP_965722.I) } \\
\text {, 3e-22, 23\% } \\
\text { (CRY } \\
\text { homologue) }\end{array}$ & $\begin{array}{c}\text { Aspergillus } \\
\text { clavatus DNA } \\
\text { photolyase, } \\
\text { putative, } 0.0 \text {, } \\
58 \% \\
(\mathrm{XP} 00127076 \\
8.1)\end{array}$ & $\begin{array}{c}\text { Gibberella zeae } \\
\text { hypothetical } \\
\text { proteinFG0676 } \\
5.1,0.0,71 \% \\
(\text { XP_38694I.I) }\end{array}$ & $\begin{array}{c}\text { hypothetical } \\
\text { protein } \\
\text { MGG_0207I, } \\
0.0,57 \% \\
\left(X P \_365369.2\right)\end{array}$ & $\begin{array}{c}\text { hypothetical } \\
\text { protein } \\
\text { UM02I I44.1, } \\
\text { Ie-135, 42\% } \\
\text { (XP_75829I.I) }\end{array}$ \\
\hline $\begin{array}{c}\text { DNA } \\
\text { photolyase }\end{array}$ & PHRI & $\begin{array}{c}\text { Hypocrea lixii } \\
\text { DNA photolyase } \\
0.0,83 \% \\
\text { (CAA08916.I) }\end{array}$ & $\begin{array}{l}\text { REII660p (phr6- } \\
\text { 4), 3e-35, 27\% } \\
\text { (AAL90322.I) }\end{array}$ & $\begin{array}{c}\text { Danio rerio } \\
\text { Cryptochrome } \\
\text { DASH, Ie-40, } \\
31 \% \\
\text { (AAH985|4.I) }\end{array}$ & None & $\begin{array}{l}\text { Deoxypyrimidi } \\
\text { ne photolyase } \\
\text { PHR-I, 0.0, } \\
66 \% \text { (P27526) }\end{array}$ & $\begin{array}{c}\text { Aspergillus } \\
\text { clavatus } \\
\text { photolyase } \\
\text { Phrl, putative, } \\
0.0,60 \% \\
(\mathrm{XP} 00126997 \\
9.1)\end{array}$ & $\begin{array}{c}\text { Fusarium } \\
\text { oxysporum } \\
\text { photolyase } 0.0, \\
75 \%, \\
(\text { AF500083.1) }\end{array}$ & $\begin{array}{c}\text { hypothetical } \\
\text { protein } \\
\text { MGG_06836, } \\
0.0,66 \% \\
\left(X P \_370339.2\right)\end{array}$ & $\begin{array}{c}\text { hypothetical } \\
\text { protein } \\
\text { UM06079.1, } \\
\text { 3e-III, 42\% } \\
(\text { XP_762226.I) }\end{array}$ \\
\hline cryptochrome & tre59726 & $\begin{array}{l}\text { Neurospora crassa } \\
\text { hypothetical } \\
\text { protein } \\
\text { NCU00582.I } \\
\text { (CRY } \\
\text { homologue), 2e- } \\
\text { II6, 39\% } \\
\text { (Q7SI68) }\end{array}$ & $\begin{array}{c}\text { photolyase, 3e- } \\
\text { 13, } \\
\text { (BAAI2067.I) }\end{array}$ & $\begin{array}{c}\text { Danio rerio } \\
\text { Cryptochrome } \\
\text { DASH,le-40, } \\
26 \% \\
(\text { NP_99|249.1) }\end{array}$ & $\begin{array}{c}\text { Arabidopsis } \\
\text { thaliana CRY3 } \\
\text { (Cryptochrome } \\
\text { 3), 2e-25, 26\% } \\
\text { (NP_56846I.2) }\end{array}$ & $\begin{array}{c}\text { hypothetical } \\
\text { protein } \\
\text { NCU00582.I, } \\
\text { 2e-II6, 39\% } \\
\text { (Q7SI68) }\end{array}$ & $\begin{array}{c}\text { Aspergillus } \\
\text { oryzae } \\
\text { unnamed } \\
\text { protein } \\
\text { product, 2e-13, } \\
37 \% \\
\text { (BAE6IIIIII) }\end{array}$ & $\begin{array}{c}\text { Gibberella zeae } \\
\text { putative } \\
\text { cryptochrome } \\
\text { DASH, 3e-100, } \\
\text { 36\% (Q4IIQ6) }\end{array}$ & $\begin{array}{c}\text { hypothetical } \\
\text { protein } \\
\text { MGCH7_ch7g } \\
\text { 783,9e-112, } \\
38 \% \\
\text { (XP_00I52268 } \\
5.1)\end{array}$ & $\begin{array}{c}\text { hypothetical } \\
\text { protein } \\
\text { UM0II I I.I, } \\
4 \mathrm{e}-42,28 \% \\
\left(\mathrm{XP}_{-} 757278.1\right)\end{array}$ \\
\hline
\end{tabular}

Nearest neighbours of the respective organisms are listed along with E-value as determined by NCBI blastp search, percent identities within fragment and GenBank accession number.

nal transduction machinery comprises $\mathrm{Ca}^{2+}$-permeable channels, Ca-pumps and -transporters as well as numerous other $\mathrm{Ca}^{2+}$ signaling proteins. These components cooperate to transduce various external signals [143,144]. The interaction of calcium signaling with the cAMP-pathway via regulation of adenylyl cyclase [145] suggests a rather widespread function of calcium in regulation of cellular events. In this signaling cascade the calcium binding protein calmodulin represents a central component which in its $\mathrm{Ca}^{2+}$-activated form is able to activate or inactivate a number of enzymes including protein kinases and phosphoprotein phosphatases and is important for regulation of stress responses in fungi [146]. A comprehensive overview of calcium signaling proteins is available for $N$. crassa, M. grisea and S. cerevisiae [146]. For H. jecorina it was shown that calmodulin (CAM1) is required for formation and secretion of xylanases [14]. Further downstream components found in the genome of $H$. jecorina include a homologue of the $\mathrm{Ca}^{2+}$ /calmodulin dependent Ser/Thr phosphatase calcineurin, which consists of a catalytic subunit, calcineurin A (CNA1) and the regulatory subunit, calcineurin B (CNAB). In N. crassa, the function of calcineurin was determined to be the regulation of hyphal tip growth and branching [147]. Also a homologue of the $N$. crassa $\mathrm{Ca}^{2+} /$ calmodulin-dependent protein kinase CAMK-1 (tre44095), which plays a role in regulation of the circadian clock in this fungus by phosphorylation of FRQ [148] was found. 7 further putative $\mathrm{Ca}^{2+}$ or calmodulin binding proteins have been detected in the genome of H. jecorina (Table 7).

Calcium signaling is mediated via controlled release of $\mathrm{Ca}^{2+}$ from internal stores. The first regulatory component in the respective cascade is phospholipase C (PLC), which becomes activated by extracellular receptors and catalyzes the hydrolysis of phosphatidylinositol 4,5-bisphosphate to diacylglycerol and inositol 1,4,5-trisphosphate. Diacylglycerol represents the physiological activator of protein kinase $\mathrm{C}$ and inositol 1,4,5-trisphosphate induces the release of $\mathrm{Ca}^{2+}$ from internal stores [149]. Thus phospholipase $\mathrm{C}$ has a central function in a transmembrane signal transduction mechanism which is known to regulate several cellular processes such as metabolism, secretion and growth. H. jecorina has four phospholipase $\mathrm{C}$ homologues showing the characteristics of eukaryotic phospholipase $\mathrm{C}$ proteins, but also one (PLC-E, ABG20593) with similarities to predominantly prokaryotic phospholipase $\mathrm{C}$ proteins. The latter one seems to have no orthologue in Neurospora crassa (Tables 8 and 9). However, no such protein has yet been characterized from fungi and since bacterial PLCs are reported to have different enzymatic characteristics than eukaryotic PLCs [150], their possible involvement in signal transduction remains to be elucidated. Bacterial PLCs do not require $\mathrm{Ca}^{2+}$ for their activity and are considerably smaller than their eukaryotic counterparts. Such PLCs have been shown to play a role in virulence in pathogenic bacteria, but in many cases their precise function remains elusive. Interestingly, it was suggested that bacterial PLCs might be descendants from eukaryotic PLCs that were incorporated by the bacteria during evolution and that the loss of requirement for a $\mathrm{Ca}^{2+}$ cofactor might have been evolutionary beneficial for bacteria living as intracellular parasites [150].

For signal dependent alteration of $\mathrm{Ca}^{2+}$ concentration $H$. jecorina has both calcium/sodium as well as calcium/proton antiporters, and calcium permeable channels available (Table 8). As for further components producing second messengers it is interesting to note that in contrast to $N$. crassa [25], H. jecorina indeed possesses a putative sphingosine kinase (tre68412) which synthesizes sphingosine-1-phosphate. 
Table 6: Casein kinases.

\begin{tabular}{|c|c|c|c|c|c|c|c|c|c|c|}
\hline Protein class & protein ID & $\begin{array}{l}\text { Best hit } \\
\text { overall }\end{array}$ & Drosophila & Animal & $\begin{array}{c}\text { Plant } \\
\text { (Viridiplantae } \\
\text { limited) }\end{array}$ & Neurospora & Aspergillus & Fusarium & $\begin{array}{c}\text { Magnaporthe } \\
\text { grisea }\end{array}$ & $\begin{array}{c}\text { Ustilago } \\
\text { maydis }\end{array}$ \\
\hline casein kinase I & HHPI & $\begin{array}{c}\text { Gibberella zeae } \\
\text { conserved } \\
\text { hypothetical } \\
\text { protein, 0.0,96\% } \\
\left(X X_{3} 388907.1\right)\end{array}$ & $\begin{array}{c}\text { Drosophila } \\
\text { melanogaster } \\
\text { double-time 2e- } \\
\text { I32,69\% } \\
\text { (AAF27857.I) }\end{array}$ & $\begin{array}{c}\text { Rattus norvegicus } \\
\text { casein kinase I } \\
\text { epsilon-2, 2e-- } \\
\text { I 44,65\% } \\
\text { (BAB32922.I) }\end{array}$ & $\begin{array}{c}\text { Oryza sativa } \\
\text { hypothetical } \\
\text { protein } \\
\text { OsJ_008513 4e- } \\
\text { I4I, 60\% } \\
\text { (EAZ25030.I) }\end{array}$ & $\begin{array}{c}\text { Neurospora } \\
\text { crassa casein } \\
\text { kinase l homomog } \\
\text { HHPI, 4e-173, } \\
82 \% \\
(\text { XP_965825.I) }\end{array}$ & $\begin{array}{c}\text { Aspergillus terreus } \\
\text { casein kinase I } \\
\text { isoform epsilon, } \\
0.0,88 \% \\
(\mathrm{XP} 001209612 . \\
\text { I) }\end{array}$ & $\begin{array}{c}\text { Gibberella zeae } \\
\text { conserved } \\
\text { hypothetical } \\
\text { protein, 0.0,96\% } \\
\left(X P \_388907.1\right)\end{array}$ & $\begin{array}{c}\text { casein kinase I, } \\
0.0,88 \% \\
\left(X_{3} \_366753.1\right)\end{array}$ & $\begin{array}{c}\text { Hypothetical } \\
\text { protein } \\
\text { UM00584.I, 3e- } \\
161,88 \% \\
\left(X P \_756731.1\right)\end{array}$ \\
\hline casein kinase I & tre 30360 & $\begin{array}{c}\text { Gibberella zeae } \\
\text { conserved } \\
\text { hypothetical } \\
\text { protein, 0.0,91\% } \\
\left(X P \_390242.1\right)\end{array}$ & $\begin{array}{c}\text { Drosophila } \\
\text { melanogaster } \\
\text { gilgamesh } \\
\text { CG6963-PA, 6e- } \\
\text { 105, 61\% } \\
\text { (NP732I23.1) }\end{array}$ & $\begin{array}{c}\text { Mus musculus } \\
\text { casein kinase I, } \\
\text { gamma 3, 3e- } \\
108,65 \% \\
(\text { NP_690022.2) }\end{array}$ & $\begin{array}{l}\text { Oryza sativa } \\
\text { casein kinase I } \\
\text { like, 2e-95, 45\% } \\
\text { (BAB92346.I) }\end{array}$ & $\begin{array}{c}\text { Neurospora } \\
\text { crassa probable } \\
\text { casein kinase I } \\
\text { cki2, 5e-177, } \\
72 \% \\
(\text { XP_957620.I) }\end{array}$ & $\begin{array}{c}\text { Aspergillus niger } \\
\text { hypothetical } \\
\text { protein } \\
\text { AnI } 8 \text { 8g6050, } \\
0.0,76 \% \\
\text { (XP_00I } 399056 . \\
\text { I) }\end{array}$ & $\begin{array}{c}\text { Gibberella zeae } \\
\text { conserved } \\
\text { hypothetical } \\
\text { protein, 0.0,9l\% } \\
\left(X P \_390242.1\right)\end{array}$ & $\begin{array}{c}\text { conserved } \\
\text { hypothetical } \\
\text { protein, } 0.0,81 \% \\
\left(X P \_3625 \mid 4.2\right)\end{array}$ & $\begin{array}{c}\text { Hypothetical } \\
\text { protein } \\
\text { UM00274.I, le- } \\
\text { 154, 86\% } \\
(\text { XP_75642I.I) }\end{array}$ \\
\hline casein kinase I & tre 12219 & $\begin{array}{c}\text { Bos taurus casein } \\
\text { kinase I, epsilon, } \\
4 \mathrm{e}-95,56 \% \\
(\mathrm{NP} 001071577 . \\
\text { I) }\end{array}$ & $\begin{array}{c}\text { Drosophila } \\
\text { melanogaster } \\
\text { double-time 8e- } \\
87,52 \% \\
\text { (AAF27857.I) }\end{array}$ & $\begin{array}{c}\text { Danio rerio } \\
\text { casein kinase I, } \\
\text { delta, le-94, } \\
56 \% \\
\text { (NP_955877.I) }\end{array}$ & $\begin{array}{c}\text { Beta vulgaris } \\
\text { casein kinase, } \\
\text { le-90,50\% } \\
\text { (ABM55249.I) }\end{array}$ & $\begin{array}{c}\text { Neurospora } \\
\text { crassa casein } \\
\text { kinase l homolog } \\
\text { HHPI, Ie-89, } \\
52 \% \\
\left(\text { XP_965 }_{9} 96525.1\right)\end{array}$ & $\begin{array}{c}\text { Aspergillus } \\
\text { fumigatus casein } \\
\text { kinase I, } \\
\text { putative, 4e-94, } \\
51 \% \\
\text { (XP_749388.I) }\end{array}$ & $\begin{array}{c}\text { Gibberella zeae } \\
\text { conserved } \\
\text { hypothetical } \\
\text { protein, le-94, } \\
55 \% \\
\text { (XP_388907.I) }\end{array}$ & $\begin{array}{c}\text { hypothetical } \\
\text { protein } \\
\text { MGCH7_ch7g58 } \\
5,3 e-94,55 \% \\
\text { (XP_001522482. } \\
\text { I) }\end{array}$ & $\begin{array}{c}\text { hypothetical } \\
\text { protein } \\
\text { UM0584.I, 6e- } \\
92,55 \% \\
\text { (XP_756731.I) }\end{array}$ \\
\hline casein kinase II & $\mathrm{KC} 2 \mathrm{~A}$ & $\begin{array}{c}\text { Gibberella zeae } \\
\text { Casein kinase II, } \\
\text { alpha chain, 3e- } \\
\text { I73,95\% } \\
(\text { XP_380853.I) }\end{array}$ & $\begin{array}{c}\text { Drosophila } \\
\text { melanogaster } \\
\text { Casein kinase II } \\
\text { subunit alpha, } \\
\text { 7e-122, 70\%, } \\
\text { (P08181) }\end{array}$ & $\begin{array}{c}\text { Danio rerio } \\
\text { similar to alpha } \\
\text { subunit of casein } \\
\text { kinase II, 2e-13I, } \\
68 \% \\
(\text { XP_699829.I) }\end{array}$ & $\begin{array}{c}\text { Arabidopsis } \\
\text { thaliana casein } \\
\text { kinase II catalytic } \\
\text { subunit, I e-I I40, } \\
73 \% \% \\
\text { (BAA0109I.I) }\end{array}$ & $\begin{array}{c}\text { Neurospora } \\
\text { crassa casein } \\
\text { kinase Il subunit } \\
\text { alpha, 2e-165, } \\
91 \% \text {, (Q8TGI3) }\end{array}$ & $\begin{array}{c}\text { Aspergillus niger } \\
\text { hypothetical } \\
\text { protein } \\
\text { AnI6g08010, } \\
\text { le-I58, } 90 \% \\
(\mathrm{XP} 001398099 \\
\text { ) }\end{array}$ & $\begin{array}{c}\text { Gibberella zeae } \\
\text { Casein kinase II, } \\
\text { alpha chain, 3e- } \\
173,95 \% \\
\left(X P \_380853.1\right)\end{array}$ & $\begin{array}{c}\text { casein kinase II, } \\
2 \mathrm{e}-168,93 \% \\
(\mathrm{XP36I} 153.1)\end{array}$ & $\begin{array}{c}\text { hypothetical } \\
\text { protein } \\
\text { UM0I I80.I, 3e- } \\
\text { I4I,78\% } \\
\left(X_{-} \text {-757327.I) }\right.\end{array}$ \\
\hline casein kinase II & tre38035 & $\begin{array}{c}\text { Coccidioides imitis } \\
\text { casein kinase II, } \\
\text { alpha chain, Ie- } \\
78,52 \% \\
\text { (XP_00 I } 248389 . \\
\text { I) }\end{array}$ & $\begin{array}{c}\text { Drosophila } \\
\text { melanogaster } \\
\text { Casein kinase II } \\
\text { subunit alpha, } \\
\text { Ie-66, 47\%, } \\
\text { (P08|8I) }\end{array}$ & $\begin{array}{c}\text { Danio rerio } \\
\text { similar to alpha } \\
\text { subunit of casein } \\
\text { kinase II, 2e-77, } \\
48 \% \\
\left(\text { XP_699829.I) }^{2} \text { 6998 }\right.\end{array}$ & $\begin{array}{c}\text { Arabidopsis } \\
\text { thaliana casein } \\
\text { kinase II catalytic } \\
\text { subunit, le-73, } \\
48 \% \\
\text { (BAA01091.I) }\end{array}$ & $\begin{array}{c}\text { Neurospora } \\
\text { crassa casein } \\
\text { kinase II subunit } \\
\text { alpha, 2e-76, } \\
51 \%,(\mathrm{Q} 8 \mathrm{~T} \text { । } 3 \text { ) }\end{array}$ & $\begin{array}{c}\text { Aspergillus } \\
\text { nidulans casein } \\
\text { kinase II subunit } \\
\text { alpha, Ie-76, } \\
51 \% \\
\left(X P \_659089.1\right)\end{array}$ & $\begin{array}{c}\text { Gibberella zeae } \\
\text { casein kinase II, } \\
\text { alpha chain 4e- } \\
74,50 \% \\
\left(X P \_380853.1\right)\end{array}$ & $\begin{array}{c}\text { casein kinase II, } \\
2 \mathrm{e}-77,52 \%, \\
(\text { XP36II53.I) }\end{array}$ & $\begin{array}{c}\text { hypothetical } \\
\text { protein } \\
\text { UM01 I I80.I, 2e- } \\
71,48 \% \\
\left(X_{-} \text {_757327.I) }\right.\end{array}$ \\
\hline casein kinase II & CKBI & $\begin{array}{c}\text { Gibberella zeae } \\
\text { hypothetical } \\
\text { protein } \\
\text { FG08607.I, 5e- } \\
146,80 \% \\
\left(X P \_388783.1\right)\end{array}$ & $\begin{array}{c}\text { Drosophila } \\
\text { melanogaster } \\
\text { casein kinase II } \\
\text { beta subunit, le- } \\
45,45 \% \\
(\mathrm{NP} 5 \text { III3I.2) }\end{array}$ & $\begin{array}{c}\text { Homo sapiens } \\
\text { casein kinase } 2 \text {, } \\
\text { beta } \\
\text { polypeptide, 2e- } \\
47,44 \% \\
\text { (CAII } 83941 . I \text { ) }\end{array}$ & $\begin{array}{c}\text { Arabidopsis } \\
\text { thaliana CKB4 } \\
\text { (Casein kinase II } \\
\text { beta subunit 4), } \\
\text { 5e-38, 42\%) } \\
\text { (NP_85042I.I) }\end{array}$ & $\begin{array}{c}\text { Neurospora } \\
\text { crassa casein } \\
\text { kinase II subunit } \\
\text { beta-I, 9e.I I36, } \\
75 \% \text { (Q8TGI2) }\end{array}$ & $\begin{array}{c}\text { Aspergillus terreus } \\
\text { casein kinase II } \\
\text { beta I subunit, } \\
\text { le-97, 56\% } \\
\text { (XP_00I21478।. } \\
\text { I) }\end{array}$ & $\begin{array}{c}\text { Gibberella zeae } \\
\text { hypothetical } \\
\text { protein } \\
\text { FG08607.I, 5e- } \\
\text { I46, 80\% } \\
(\text { XP_388783.I) }\end{array}$ & $\begin{array}{c}\text { hypothetical } \\
\text { protein } \\
\text { MGG_00446, } \\
\text { 3e-12I, 7I\% } \\
\text { (XP_368798.I) }\end{array}$ & $\begin{array}{c}\text { hypothetical } \\
\text { protein } \\
\text { UM0I094.I, I e- } \\
61,46 \% \\
\left(X P \_75724 \mid . I\right)\end{array}$ \\
\hline casein kinase II & CKB2 & $\begin{array}{c}\text { Gibberella zeae } \\
\text { hypothetical } \\
\text { protein } \\
\text { FG0I288.I, 3e- } \\
126,91 \% \\
\left(X P \_38 \mid 464.1\right)\end{array}$ & $\begin{array}{c}\text { Drosophila } \\
\text { melanoaster } \\
\text { casein kinase II } \\
\text { beta subunit, Ie- } \\
56,48 \% \\
(\mathrm{NP} 5 \mathrm{II} \mid 31.2)\end{array}$ & $\begin{array}{c}\text { Canis familiaris } \\
\text { similar to casein } \\
\text { kinase 2, beta } \\
\text { subunit, 9e-59, } \\
50 \% \\
\text { (XP_532075.2) }\end{array}$ & $\begin{array}{c}\text { Zea mays } \\
\text { protein kinase } \\
\text { CK2, regulatory } \\
\text { subunit CK2BI, } \\
\text { 2e-58,53\% } \\
\text { (AAG36869.I) }\end{array}$ & $\begin{array}{c}\text { Neurospora } \\
\text { crassa casein } \\
\text { kinase II subunit } \\
\text { beta-2, 3e-II0, } \\
\text { 87\% (Q8TGII) }\end{array}$ & $\begin{array}{c}\text { Aspergillus terreus } \\
\text { casein kinase II } \\
\text { beta } 2 \text { subunit, } \\
\text { 9e-96, 78\% } \\
\text { (XP_00I210278. } \\
\text { I) }\end{array}$ & $\begin{array}{c}\text { Gibberella zeae } \\
\text { hypothetical } \\
\text { protein } \\
\text { FG0I288.I, 3e- } \\
\text { 126,91\% } \\
\text { (XP_38I464.I) }\end{array}$ & $\begin{array}{c}\text { hypothetical } \\
\text { protein } \\
\text { MGG_0565I, } \\
\text { 3e-72, 81\% } \\
\text { (XP_360277.2) }\end{array}$ & $\begin{array}{c}\text { hypothetical } \\
\text { protein } \\
\text { UM06107.I, 4e- } \\
68,58 \% \\
\left(X P \_762254.1\right)\end{array}$ \\
\hline casein kinase II & GSK3 & $\begin{array}{c}\text { Gibberella zeae } \\
\text { hypothetical } \\
\text { protein } \\
\text { FG07329.1, 0.0, } \\
92 \% \\
\left(X P \_387505.1\right)\end{array}$ & $\begin{array}{c}\text { Drosophila } \\
\text { melanogaster } \\
\text { shaggy, 2e-129, } \\
64 \% \\
(\mathrm{NP} 001036259 . \\
\text { I) }\end{array}$ & $\begin{array}{c}\text { Homo sapiens } \\
\text { glycogen } \\
\text { synthase kinase- } \\
3 \text { beta, } 3 \mathrm{e}-133 \text {, } \\
63 \%(\mathrm{P} 4984 \mathrm{I})\end{array}$ & $\begin{array}{c}\text { Triticum aestivum } \\
\text { shaggy-like } \\
\text { kinase, } 7 \mathrm{e}-122, \\
63 \% \\
(\text { BAF36565.I) }\end{array}$ & $\begin{array}{c}\text { Neurospora } \\
\text { crassa glycogen } \\
\text { synthase kinase- } \\
3,0.0,89 \% \\
\text { (AAS68519.I) }\end{array}$ & $\begin{array}{c}\text { Aspergillus } \\
\text { clavatus glycogen } \\
\text { synthase kinase } \\
\text { (SkpI), 0.0, 83\% } \\
(\text { XP_001270035. } \\
\text { I) }\end{array}$ & $\begin{array}{c}\text { Gibberella zeae } \\
\text { hypothetical } \\
\text { protein } \\
\text { FG07329.I, 0.0, } \\
92 \% \\
\left(X P_{3} 387505.1\right)\end{array}$ & $\begin{array}{c}\text { glycogen } \\
\text { synthase kinase, } \\
0.0,90 \% \\
\text { (ABA0207I.I) }\end{array}$ & $\begin{array}{c}\text { Ustilago hordei } \\
\text { glycogen } \\
\text { synthase kinase, } \\
\text { 3e-149, 66\% } \\
\text { (CAJ42002.I) }\end{array}$ \\
\hline
\end{tabular}




\section{Ras-like GTPases}

The superfamily of small Ras-like GTPases comprises several subgroups (a subgroup hierarchy is given on NCBI CDD for domain cd00876 (Ras): [151]) and regulate various cellular signaling pathways including cell growth, differentiation, proliferation and apoptosis [152]. These proteins represent monomeric GTPases that function as molecular switches by cycling between an inactive, GDPbound and an active GTP-bound state. Activation of Ras proteins is stimulated by guanine nucleotide exchange factors (GEFs), which promote exchange of GDP for GTP hence inducing a conformational change that permits interaction with downstream effectors. The duration of the active phase of Ras is limited by its intrinsic GTPase activity, which is strongly accelerated by GTPase activating proteins (GAPs). Thus GAPs can rapidly terminate the respective transduced signal $[153,154]$.

Numerous studies dealt with the elucidation of the function of Ras-like GTPases in S. cerevisiae. In this organism, the Ras proteins are presumed to mediate signaling to adenylate cyclase $[155,156]$, although this function has been debated thereafter [66] and the same is valid for a potential activation of Ras2 by the G-protein coupled receptor Gpa2 in yeast. Nevertheless a connection of Ras proteins to the cAMP-pathway is obvious and a role for Cdc25 and Ras in signaling of glucose availability has been suggested
([66] and references therein). However, for A. nidulans RasA and CAMP signaling are reported to proceed independently during germination [157]. A further signaling system targeted by Ras-GTPases is that of the MAP kinases. Here especially for the pheromone pathway an involvement of Cdc42, which activates Ste20 in yeast has been shown [71]. Ste20, which has an orthologue in H. jecorina (tre104364), thereby triggers activation of the pheromone response-MAP kinase cascade. Moreover the two component signaling response regulator $\operatorname{Skn} 7$ and the protein kinase Pkc1 (putative H. jecorina orthologues tre 44708 and PKC1, respectively) are downstream effectors of Rho1-GTP [158]. Hence all three MAPkinase pathways postulated for $H$. jecorina could be subject to regulation by Ras-GTPases. Although detailed studies of Ras-like GTPases in filamentous fungi are scarce, potential indications as to the functions of at least some of these proteins can be deduced from their interaction characteristics and roles in yeast.

The putative homologues to the members of the Ras superfamily of small GTPases as well as GEFs and GAPs found in the genome of $H$. jecorina were grouped into the respective subgroups according to the presence of the characteristic domains as determined by InterPro [159] and NCBI CDD-search [160] as well as according to their

Table 7: Proteins involved in Calcium signaling

\begin{tabular}{|c|c|c|}
\hline class of protein & ID & subtype \\
\hline Phospholipase C & $\begin{array}{c}\text { tre60। } 94 \\
\text { tre753II } \\
\text { tre37I } 43 \\
\text { tre6 I746 } \\
\text { PLC-E }\end{array}$ & \\
\hline \multirow[t]{2}{*}{ Calmodulin } & $\begin{array}{c}\text { CAMI } \\
\text { tre65659 }\end{array}$ & \\
\hline & CNAI & catalytic subunit \\
\hline Calcineurin & CNAB & regulatory subunit \\
\hline $\mathrm{Ca} 2+$ and/or $\mathrm{CaM}$ binding proteins & $\begin{array}{c}\text { CMK2 } \\
\text { trel8772 } \\
\text { tre44095 } \\
\text { trel I9679 } \\
\text { tre4453I } \\
\text { tre64I } 96 \\
\text { tre42I } 43 \\
\text { tre33I } 28\end{array}$ & \\
\hline Calnexin/Calreticulin & tre43732 & \\
\hline Calpactin I heavy chain & $\begin{array}{l}\text { tre21646 } \\
\text { tre29619 }\end{array}$ & \\
\hline
\end{tabular}


S. cerevisiae orthologues and their targets (in case of GEFs and GAPs) (Table 10).

Interestingly, $H$. jecorina has a considerable number of these small GTPases at its disposal, although due to the lack of comprehensive studies in other fungi, this does not necessarily indicate an expansion of this group. In Table 10 an overview of the groups present is given along with the putative modulators (GEFs and GAPs), if a correlation based on the yeast orthologues (GenBank, NCBI) was possible. Consequently $H$. jecorina has at least 10 Rab-type GTPases putatively modulated by 1 GEF and 6 GAPs, 9 Rho-type GTPases targeted by 2 GEFs and 4 GAPs, 5 Rastype GTPases subject to (de)activation by 4 GEFs and 3 GAPs, 7 Arf (ADP-ribosylation factor like) GTPases possibly influenced by 3 GEFs as well as one Ran-type and one Rac-type GTPase, for which no regulatory factors have been identified. Furthermore two GAPs have been found that could not be assigned to a specific group.

In particular the orthologues of the Ras-subtype GTPases RAS1 and RAS2 together with their modulators (tre34726, tre107369, tre61408, tre22757) are reported to influence the cAMP dependent protein kinase A [66] in S. cerevisiae and are involved in a G-protein/cAMP/protein kinase A signaling pathway regulating aflR expression in $A$. nidulans [161]. They could therefore have a function in the processes connected to such a pathway in $H$. jecorina such as cellulase gene expression or light response. Moreover a function in regulation of conidial germination, morphology and asexual development has been shown in A. nidu-
Table 8: $\mathrm{Ca}^{2+}$ permeable channels, Cation pumps and $\mathrm{Ca}^{2+}$ transporters

\begin{tabular}{|c|c|c|}
\hline class of protein & ID & subtype \\
\hline $\mathrm{Ca} 2+$ permeable channel & $\begin{array}{l}\text { tre23028 } \\
\text { tre37060 } \\
\text { tre74057 }\end{array}$ & \\
\hline \multirow[t]{2}{*}{ Cation pumps } & $\begin{array}{c}\text { tre } 43358 \\
\text { tre75347 } \\
\text { tre58952 } \\
\text { tre62362 } \\
\text { tre8I536 } \\
\text { tre } 122972 \\
\text { tre8I } 1430 \\
\text { tre2322I } \\
\text { tre4I593 } \\
\text { trel } 123183\end{array}$ & \\
\hline & $\begin{array}{l}\text { tre79599 } \\
\text { tre55595 }\end{array}$ & $\mathrm{Ca} 2+/$ proton exchangers \\
\hline $\mathrm{Ca} 2+$ transporters & $\begin{array}{c}\text { tre } 19432 \\
\text { tre56744 } \\
\text { tre82544 } \\
\text { tre68169 } \\
\text { tre62835 } \\
\text { tre76557 } \\
\text { tre4l7I }\end{array}$ & $\mathrm{Ca} 2+/ \mathrm{Na}+$ exchangers \\
\hline
\end{tabular}

lans [157,162-164]. Also two Rho-type GTPase orthologues of $\mathrm{H}$. jecorina, RHO1 and CDC42, which have functions upstream of MAP kinase pathways in S. cerevisiae [71] might also in H. jecorina establish an important

Table 9: Phospholipase C proteins.

\begin{tabular}{|c|c|c|c|c|c|}
\hline protein ID & Best hit overall & Neurospora & Prokaryote & Fusarium & Animal \\
\hline tre60194 & $\begin{array}{c}\text { Gibberella zeae } \\
\text { hypothetical protein } \\
\text { FG05898.I, 0.0, 56\% } \\
\text { (XP_386074.I) }\end{array}$ & $\begin{array}{c}\text { Neurospora crassa probable } \\
\text { phosphoinositide-specific } \\
\text { phospholipase C } \\
\text { NCU0I266.I, 0.0, 43\% } \\
\text { (XP_960744.I) }\end{array}$ & None & $\begin{array}{c}\text { Gibberella zeae } \\
\text { hypothetical protein } \\
\text { FG05898.I, 0.0, 56\% } \\
\text { (XP_386074.I) }\end{array}$ & $\begin{array}{c}\text { Macaca mulatta similar } \\
\text { to phospholipase C, } 4 \mathrm{e}- \\
73,29 \% \\
(\mathrm{XP} \text {-00109|488.I) }\end{array}$ \\
\hline tre753II & $\begin{array}{c}\text { Phaeosphaeria nodorum } \\
\text { hypothetical protein } \\
\text { SNOG_09944, 0.0, 58\% } \\
\text { (EAT82279.I) }\end{array}$ & $\begin{array}{c}\text { Neurospora crassa } \\
\text { hypothetical protein } \\
\text { NCU09655.I, 4e-82, 48\% } \\
\text { (EAA29485.I) }\end{array}$ & None & $\begin{array}{c}\text { Gibberella zeae } \\
\text { hypothetical protein } \\
\text { FG05060.I, 0.0, 56\% } \\
\text { (XP_385236.I) }\end{array}$ & $\begin{array}{c}\text { Rattus norvegicus } \\
\text { phospholipase C, delta } \\
\text { I, 2e-4I, 28\% (PI 0688) }\end{array}$ \\
\hline tre37/43 & $\begin{array}{c}\text { Gibberella zeae } \\
\text { hypothetical protein } \\
\text { FG8790.I, 3e-164, 50\% } \\
\text { (XP_388966.I) }\end{array}$ & $\begin{array}{c}\text { Neurospora crassa } \\
\text { phospholipase C } \\
\text { NCU06245.I, I e-98, 39\% } \\
\text { (AAZ23804.I) }\end{array}$ & None & $\begin{array}{c}\text { Gibberella zeae } \\
\text { hypothetical protein } \\
\text { FG8790.I, 3e-I64, 50\% } \\
(\text { XP_388966.I) }\end{array}$ & $\begin{array}{l}\text { Homo sapiens PLCD3 } \\
\text { protein, 7e-35, 27\% } \\
\text { (AAHI0668.2) }\end{array}$ \\
\hline tre61746 & $\begin{array}{c}\text { Gibberella zeae } \\
\text { hypothetical protein } \\
\text { FG06693.I, 0.0, 52\% } \\
\text { (XP_386869.1) }\end{array}$ & $\begin{array}{c}\text { Neurospora crassa } \\
\text { phospholipase C } \\
\text { NCU06245.I, 9e-160, 46\% } \\
\text { (AAZ23804.I) }\end{array}$ & None & $\begin{array}{c}\text { Gibberella zeae } \\
\text { hypothetical protein } \\
\text { FG06693.I, 0.0,52\% } \\
\text { (XP_386869.1) }\end{array}$ & $\begin{array}{l}\text { Rattus norvegicus similar } \\
\text { to phospholipase C, } \\
\text { delta 3, le-42, 32\% } \\
\text { (XP_221004.4) }\end{array}$ \\
\hline PLC-E & $\begin{array}{c}\text { Gibberella zeae } \\
\text { hypothetical protein } \\
\text { FGII } 236.1,0.0,62 \% \\
\left(X P \_39|4| 2.1\right)\end{array}$ & None & $\begin{array}{c}\text { Burkholderia dolosa } \\
\text { Phospholipase C, Ie- } \\
68,33 \% \\
\text { (EAY6774I.I) }\end{array}$ & $\begin{array}{c}\text { Gibberella zeae } \\
\text { hypothetical protein } \\
\text { FGII } 236.1,0.0,62 \% \\
\left(X P \_39|4| 2.1\right)\end{array}$ & None \\
\hline
\end{tabular}

Nearest neighbours of the respective organisms are listed along with E-value as determined by NCBI blastp search, percent identities within fragment and GenBank accession number. 
Table 10: The superfamily of Ras small GTPases

\begin{tabular}{|c|c|c|c|}
\hline Ras subfamily & Ras GTPase & RasGEF & RasGAP \\
\hline & & & tre22132 \\
\hline & YPTI & & \\
\hline & $\begin{array}{l}\text { tre } 17707 \\
\text { tre30910 }\end{array}$ & & trel21349 \\
\hline & tre44333 & tre75397 & \\
\hline \multirow[t]{4}{*}{ Rab } & tre44010 & & $\begin{array}{l}\text { tre65982 } \\
\text { tre } 44704 \\
\text { tre4425 I }\end{array}$ \\
\hline & $\begin{array}{l}\text { tre33269 } \\
\text { tre31007 } \\
\text { tre4206I } \\
\text { tre42834 } \\
\text { tre295I5 }\end{array}$ & & \\
\hline & & & tre35375 \\
\hline & $\begin{array}{c}\text { tre2 } 1294 \\
\text { trel } 06302 \\
\text { tre4 } 1009 \\
\text { tre5278 }\end{array}$ & & \\
\hline \multirow[t]{4}{*}{ Rho } & CDC42 & tre30184 & tre74848 \\
\hline & GEMI & & \\
\hline & $\begin{array}{c}\text { tre53562 } \\
\text { RHO3 }\end{array}$ & & $\begin{array}{l}\text { tre } 14881 \\
\text { tre46043 }\end{array}$ \\
\hline & RHOI & tre37105 & tre807I3 \\
\hline \multirow{7}{*}{ Ras } & $\begin{array}{c}\text { trel } 07035 \\
\text { tre } 66480\end{array}$ & & \\
\hline & RASI & & \\
\hline & RAS2 & & \\
\hline & & tre 107369 & \\
\hline & RSRI (Rap-like) & & tre8I 785 \\
\hline & & tre 67275 & \\
\hline & & tre70548 & \\
\hline \multirow[t]{3}{*}{ Ran } & RANI & & \\
\hline & $\begin{array}{l}\text { tre } 28367 \\
\text { tre43I } 77\end{array}$ & & \\
\hline & tre29890 & tre28378 & \\
\hline Arf-like & tre45468 & tre29839 & \\
\hline
\end{tabular}

regulatory bridge between cell surface receptors and this crucial signaling system. Given the high number of Rassuperfamily genes found in the $H$. jecorina genome and the numerous putative functions with predicted links to almost every signaling system studied so far, elucidation of their roles in signal transduction could contribute considerably to a better understanding of some as yet enigmatic phenomena.

\section{Conclusion}

Being an industrial workhorse, interest in signal transduction processes of $H$. jecorina has been limited so far. However, given the intriguing uniqueness of the enzymatic machinery of this fungus [7], it is tempting to speculate that sophisticated and efficient regulation of the surprisingly small number of degradative enzymes has enabled $H$. jecorina to efficiently compete in nature. Therefore an equally efficient system for perception and interpretation of environmental signals is indispensable. Although signal transduction pathways of $H$. jecorina are largely comparable with those of other filamentous fungi, also in several cases expansions of certain classes and missing of others has been detected. These alterations as well as the global signaling network optimized for survival in nature despite certain enzymatic shortcommings is likely to provide insights into crucial environmental cues causing regulatory adjustments in $H$. jecorina, which can be exploited to improve industrial fermentations.

\section{Methods}

\section{Genome assembly information}

The Hypocrea jecorina QM6a DNA sequence and protein predictions of the Trichoderma reesei genome database ver2.0 by the Joint Genome Institute http://genome.jgipsf.org/Trire2/Trire2.home.html were used for this study (AAIL00000000). For comparison also the genome databases at the Joint Genome institute server [165] of the Fungal Genome Initiative [166], especially those of Aspergillus nidulans [167], Neurospora crassa [168], and Magnaporthe grisea [169] were used.

\section{Gene identification}

In order to identify a specific gene, the putative orthologue of N. crassa [25] was used for a TBLASTN search on the $T$. reesei genome database. If no orthologue was available in N. crassa, the orthologue of the organism in which the respective protein had been characterized was used. In cases where the assignment to a certain orthologue was unclear (especially if the similarity was poor), the predicted protein model of $T$. reesei was again used for a TBLASTN search in the respective genome to check whether the respective protein was the true orthologue of the protein used for the identification. In some cases the model as provided by the automatic annotation was adjusted manually, especially if the start- or stop codon 
Table 10: The superfamily of Ras small GTPases (Continued)

\begin{tabular}{ccr}
\hline & tre38187 & tre37547 \\
\cline { 2 - 3 } & $\begin{array}{c}\text { tre42316 } \\
\text { SARI }\end{array}$ & \\
\hline Rac & RACI & \\
\hline \multirow{2}{*}{ undetermined } & & tre62426 \\
& & tre37068
\end{tabular}

The respective small GTPases are grouped according to their assigned subfamily as suggested by the presence of appropriate protein domains determined by InterPro and NCBI CDD search as well as due to their similarity to known orthologues in GenBank. Guanine nucleotide exchange factors (GEFs) and GTPase activating proteins (GAPs) have been associated with the respective GTPase(s), provided that the regulatory target of the orthologue in yeast was known.

was missing or the protein model differed significantly from orthologues in other fungi. The sequence information, protein- and domain predictions were used as provided on the genome database homepage and crosschecked by NCBI CDD search [170] http:// www.ncbi.nlm.nih.gov/Structure/cdd/wrpsb.cgi, InterProScan [159] and NCBI Blastp [171,172].

Genes and encoded proteins were denominated according to the guidelines for $T$. reesei ( $H$. jecorina) genome annotation: the name contains the prefix "tre" followed by the protein ID of the best model as suggested by in silico modelling and annotation within the Genome Browser of the Trichoderma reesei genome database ver 2.0 or as determined manually by the respective annotator. If amino acid similarity of the respective model to a characterized protein exceeds $80 \%$, these proteins are considered homologues and the $H$. jecorina protein is named after the homologous protein in three letter code followed by a number. In any case, N. crassa denomination of homologous proteins is preferred. The Trichoderma reesei genome database ver2.0 is publicly accessible free of charge.

\section{Sequence alignment and phylogenetic analysis}

Sequence alignments were performed using ClustalX (1.81) [173] and the alignment was manually adjusted by the aid of Genedoc. The evolutionary relationships were inferred using the Minimum Evolution method [174] and the software MEGA4. The percentage of replicate trees in which the associated proteins clustered together in the bootstrap test (500 replicates) are shown next to the branches [175]. The trees are drawn to scale, with branch lengths in the same units as those of the evolutionary distances used to infer the phylogenetic tree. The evolutionary distances were computed using the Poisson correction method [176] and are in the units of the number of amino acid substitutions per site. The ME tree was searched using the Close-Neighbor-Interchange (CNI) algorithm [177] at a search level of 1 . The Neighbor-joining algorithm [178] was used to generate the initial tree. All positions containing gaps and missing data were eliminated from the dataset (Complete deletion option). There were a total of 128 positions in the final dataset. Phylogenetic analyses were conducted in MEGA4 [179].

\section{Acknowledgements}

This work was supported by the Austrian Science Fund grant FWF P-I 17325. $\mathrm{MS}$ is recipient of an APART fellowship of the Austrian Academy of Sciences at the Institute of Chemical engineering, TU Vienna. The T. reesei Genome Sequencing Project was funded by the United States Department of Energy.

\section{References}

I. Mandels M, Reese ET: Induction of cellulase in Trichoderma viride as influenced by carbon sources and metals. I Bacteriol 1957, 73(2):269-278.

2. Buchert J, Oksanen T, Pere J, Siika-Aho M, Suurnäkki A, Viikari L: Applications of Trichoderma reesei enzymes in the pulp and paper industry. In Trichoderma \& Gliocladium Volume 2. Edited by: Harman GE, Kubicek CP. London: Taylor \& Francis; 1998:343-363.

3. Galante Y, De Conti A, Monteverdi R: Application of Trichoderma enzymes in the textile industry. In Trichoderma \& Gliocladium Edited by: Harman GE, Kubicek CP. London: Taylor \& Francis; 1998:31I-325.

4. Galante Y, De Conti A, Monteverdi R: Application of Trichoderma enzymes in the food and feed industries. In Trichoderma and Gliocladium Edited by: Harman GE, Kubicek CP. London: Taylor \& Francis; 1998:327-342.

5. Keranen S, Penttila M: Production of recombinant proteins in the filamentous fungus Trichoderma reesei. Curr Opin Biotechnol 1995, 6(5):534-537.

6. Mach L, Zeilinger S: Regulation of gene expression in industrial fungi: Trichoderma. Appl Microbiol Biotechnol 2003, 60(5):5I5-522.

7. Martinez D, Berka RM, Henrissat B, Saloheimo M, Arvas M, Baker SE, Chapman J, Chertkov O, Coutinho PM, Cullen D, et al.: Genome sequencing and analysis of the biomass-degrading fungus Trichoderma reesei (syn. Hypocrea jecorina). Nat Biotechnol 2008, 26(5):553-560.

8. Schmoll M, Kubicek CP: Regulation of Trichoderma cellulase formation: lessons in molecular biology from an industrial fungus. A review. Acta Microbiol Immunol Hung 2003, 50(2-3): I25-I 45.

9. Seidl V, Schmoll M, Scherm B, Balmas V, Seiboth B, Migheli Q, Kubicek CP: Antagonism of Pythium blight of zucchini by Hypocrea jecorina does not require cellulase gene expression but is improved by carbon catabolite derepression. FEMS Microbiol Lett 2006, 257(I):|45-|5|.

10. Lengeler KB, Davidson RC, D'Souza C, Harashima T, Shen WC Wang P, Pan X, Waugh M, Heitman J: Signal transduction cascades regulating fungal development and virulence. Microbiol Mol Biol Rev 2000, 64(4):746-785.

1I. Read ND: Environmental sensing and the filamentous lifestyle. In Fungi in the Environment Edited by: Gadd GM, Watkinson SC, Dyer PS. Cambridge University Press; 2006:38-56.

12. Schmoll M, Franchi L, Kubicek CP: Envoy, a PAS/LOV domain protein of Hypocrea jecorina (Anamorph Trichoderma reesei), modulates cellulase gene transcription in response to light. Eukaryot Cell 2005, 4(1 2): 1998-2007.

13. Schuster A, Kubicek CP, Friedl MA, Druzhinina IS, Schmoll M: Impact of light on Hypocrea jecorina and the multiple cellular roles of ENVOY in this process. BMC Genomics 2007, 8(I):449.

14. Mach RL, Zeilinger S, Kristufek D, Kubicek CP: Ca2+-calmodulin antagonists interfere with xylanase formation and secretion in Trichoderma reesei. Biochim Biophys Acta 1998, 1403(3):28I-289.

15. Trichoderma reesei genome database ver2.0 [http://genome.jgipsf.org/Trire2/Trire2.home.html]

16. Galagan JE, Calvo SE, Borkovich KA, Selker EU, Read ND, Jaffe D, FitzHugh W, Ma LJ, Smirnov S, Purcell S, et al.: The genome sequence of the filamentous fungus Neurospora crassa. Nature 2003, 422(6934):859-868. 
17. Cuomo CA, Guldener U, Xu JR, Trail F, Turgeon BG, Di Pietro A, Walton JD, Ma LJ, Baker SE, Rep M, et al:: The Fusarium graminearum genome reveals a link between localized polymorphism and pathogen specialization. Science 2007, 3 I7(5843): 1400-I 402.

18. Birnbaumer L: Receptor-to-effector signaling through G proteins: roles for beta gamma dimers as well as alpha subunits. Cell 1992, 7 I(7): 1069-1072.

19. Oldham WM, Hamm HE: Heterotrimeric G protein activation by G-protein-coupled receptors. Nat Rev Mol Cell Biol 2008 9(1):60-7I.

20. Hamm HE: The many faces of G protein signaling. I Biol Chem 1998, 273(2):669-672.

21. Neer E): Heterotrimeric $\mathbf{G}$ proteins: organizers of transmembrane signals. Cell 1995, 80(2):249-257.

22. Cabrera-Vera TM, Vanhauwe J, Thomas TO, Medkova M, Preininger A, Mazzoni MR, Hamm HE: Insights into G protein structure, function, and regulation. Endocr Rev 2003, 24(6):765-78I.

23. Lafon $A$, Han $K H$, Seo JA, Yu JH, d'Enfert C: G-protein and cAMP. mediated signaling in aspergilli: a genomic perspective. Fungal Genet Biol 2006, 43(7):490-502.

24. Li L, Wright SJ, Krystofova S, Park G, Borkovich KA: Heterotrimeric $\mathbf{G}$ protein signaling in filamentous fungi. Annu Rev Microbiol 2007, 61:423-452.

25. Borkovich KA, Alex LA, Yarden O, Freitag M, Turner GE, Read ND, Seiler S, Bell-Pedersen D, Paietta J, Plesofsky N, et al.: Lessons from the genome sequence of Neurospora crassa: tracing the path from genomic blueprint to multicellular organism. Microbiol Mol Biol Rev 2004, 68(I): I- 108

26. Lafon A, Seo JA, Han KH, Yu JH, d'Enfert C: The heterotrimeric G-protein GanB(alpha)-SfaD(beta)-GpgA(gamma) is a carbon source sensor involved in early CAMP-dependent germination in Aspergillus nidulans. Genetics 2005, I7I(I):7I-80.

27. Reithner B, Brunner K, Schuhmacher R, Peissl I, Seidl V, Krska R, Zeilinger S: The $\mathbf{G}$ protein alpha subunit Tgal of Trichoderma atroviride is involved in chitinase formation and differential production of antifungal metabolites. Fungal Genet Biol 2005, 42(9):749-760.

28. Rocha-Ramirez V, Omero C, Chet I, Horwitz BA, Herrera-Estrella A Trichoderma atroviride G-protein alpha-subunit gene tgal is involved in mycoparasitic coiling and conidiation. Eukaryot $\mathrm{Cell}$ 2002, I(4):594-605.

29. Yang Q, Poole SI, Borkovich KA: A G-protein beta subunit required for sexual and vegetative development and maintenance of normal G alpha protein levels in Neurospora crassa. Eukaryot Cell 2002, I(3):378-390.

30. Komon-Zelazowska M, Neuhof T, Dieckmann R, von Dohren $\mathrm{H}$, Herrera-Estrella A, Kubicek CP, Druzhinina IS: Formation of atroviridin by Hypocrea atroviridis is conidiation associated and positively regulated by blue light and the G protein GNA3. Eukaryot Cell 2007, 6(I 2):2332-2342.

3I. Zeilinger S, Reithner B, Scala V, PeissI I, Lorito M, Mach RL: Signal transduction by Tga3, a novel $\mathbf{G}$ protein alpha subunit of Trichoderma atroviride. Appl Environ Microbiol 2005, 7 I(3): I59|-I597.

32. Regenfelder E, Spellig T, Hartmann A, Lauenstein S, Bolker M, Kahmann R: G proteins in Ustilago maydis: transmission of multiple signals? EMBO J 1997, 16(8):1934-1942.

33. Harashima T, Heitman J: The Galpha protein Gpa2 controls yeast differentiation by interacting with kelch repeat proteins that mimic Gbeta subunits. Mol Cell 2002, I0(I):163-173.

34. Peeters T, Versele M, Thevelein JM: Directly from Galpha to protein kinase $A$ : the kelch repeat protein bypass of adenylate cyclase. Trends Biochem Sci 2007, 32(1 2):547-554.

35. Bieszke JA, Braun EL, Bean LE, Kang S, Natvig DO, Borkovich KA: The nop-I gene of Neurospora crassa encodes a seven transmembrane helix retinal-binding protein homologous to archaeal rhodopsins. Proc Natl Acad Sci USA 1999 , 96( I 4):8034-8039.

36. Bieszke JA, Li L, Borkovich KA: The fungal opsin gene nop-I is negatively-regulated by a component of the blue light sensing pathway and influences conidiation-specific gene expression in Neurospora crassa. Curr Genet 2007, 52(3-4): I 49-157.

37. Bieszke JA, Spudich EN, Scott KL, Borkovich KA, Spudich JL: A eukaryotic protein, NOP-I, binds retinal to form an archaeal rhodopsin-like photochemically reactive pigment. Biochemistry 1999, 38(43): $14|38-14| 45$.
38. Xue Y, Batlle M, Hirsch JP: GPR I encodes a putative G proteincoupled receptor that associates with the Gpa2p Galpha subunit and functions in a Ras-independent pathway. EMBO J 1998, 17(7): 1996-2007.

39. Welton RM, Hoffman CS: Glucose monitoring in fission yeast via the Gpa2 galpha, the git5 Gbeta and the git3 putative glucose receptor. Genetics 2000, I 56(2):513-52I.

40. Nectria haematococca genome database at the Joint Genome institute (DOE) [http://genome.jgi-psf.org/Necha2/ Necha2.home.html]

41. DeZwaan TM, Carroll AM, Valent B, Sweigard JA: Magnaporthe grisea pth I Ip is a novel plasma membrane protein that mediates appressorium differentiation in response to inductive substrate cues. Plant Cell I999, I I (I0):2013-2030.

42. Kulkarni RD, Thon MR, Pan H, Dean RA: Novel G-protein-coupled receptor-like proteins in the plant pathogenic fungus Magnaporthe grisea. Genome Biol 2005, 6(3):R24.

43. Lee RH, Fowler A, McGinnis JF, Lolley RN, Craft CM: Amino acid and CDNA sequence of bovine phosducin, a soluble phosphoprotein from photoreceptor cells. I Biol Chem 1990, 265(26): 15867- 15873

44. Kasahara $S$, Wang P, Nuss DL: Identification of bdm-I, a gene involved in $\mathbf{G}$ protein beta-subunit function and alpha-subunit accumulation. Proc Natl Acad Sci USA 2000, 97(1):4 I 2-4I7.

45. Seo JA, Yu JH: The phosducin-like protein PhnA is required for Gbetagamma-mediated signaling for vegetative growth, developmental control, and toxin biosynthesis in Aspergillus nidulans. Eukaryot Cell 2006, 5(2):400-4I0.

46. Bauer PH, Muller S, Puzicha M, Pippig S, Obermaier B, Helmreich EJ, Lohse MJ: Phosducin is a protein kinase A-regulated G-protein regulator. Nature 1992, 358(638 I):73-76.

47. Lee RH, Ting TD, Lieberman BS, Tobias DE, Lolley RN, Ho YK: Regulation of retinal cGMP cascade by phosducin in bovine rod photoreceptor cells. Interaction of phosducin and transducin. J Biol Chem 1992, 267(35):25I04-25III2

48. McLaughlin JN, Thulin CD, Hart SJ, Resing KA, Ahn NG, Willardson BM: Regulatory interaction of phosducin-like protein with the cytosolic chaperonin complex. Proc Natl Acad Sci USA 2002, 99(I 2):7962-7967.

49. Stirling PC, Srayko M, Takhar KS, Pozniakovsky A, Hyman AA, Leroux MR: Functional interaction between phosducin-like protein 2 and cytosolic chaperonin is essential for cytoskeletal protein function and cell cycle progression. Mol Biol Cell 2007, 18(6):2336-2345

50. Willardson BM, Howlett AC: Function of phosducin-like proteins in $G$ protein signaling and chaperone-assisted protein folding. Cell Signal 2007, 19(I 2):2417-2427.

5I. Blaauw M, Knol JC, Kortholt A, Roelofs J, Ruchira , Postma M, Visser AJ, van Haastert PJ: Phosducin-like proteins in Dictyostelium discoideum: implications for the phosducin family of proteins. EMBO J 2003, 22(19):5047-5057.

52. Miles MF, Barhite S, Sganga M, Elliott M: Phosducin-like protein: an ethanol-responsive potential modulator of guanine nucleotide-binding protein function. Proc Natl Acad Sci USA 1993, 90(22): $1083 \mid-10835$

53. Gaudet R, Bohm A, Sigler PB: Crystal structure at $\mathbf{2 . 4}$ angstroms resolution of the complex of transducin betagamma and its regulator, phosducin. Cell 1996, 87(3):577-588.

54. Flanary PL, DiBello PR, Estrada P, Dohlman HG: Functional analysis of PIpI and PIp2, two homologues of phosducin in yeast. I Biol Chem 2000, 275: 18462-18469.

55. Hollinger S, Hepler JR: Cellular regulation of RGS proteins: modulators and integrators of $\mathbf{G}$ protein signaling. Pharmacol $\operatorname{Rev}$ 2002, 54(3):527-559.

56. Han $\mathrm{KH}$, Seo JA, Yu JH: Regulators of G-protein signalling in Aspergillus nidulans: RgsA downregulates stress response and stimulates asexual sporulation through attenuation of GanB (Galpha) signalling. Mol Microbiol 2004, 53(2):529-540.

57. Kohout TA, Lefkowitz RJ: Regulation of $\mathbf{G}$ protein-coupled receptor kinases and arrestins during receptor desensitization. Mol Pharmacol 2003, 63(1):9-18.

58. Luttrell LM, Lefkowitz RJ: The role of beta-arrestins in the termination and transduction of G-protein-coupled receptor signals. J Cell Sci 2002, I I5(Pt 3):455-465. 
59. Caddick MX, Brownlee AG, Arst HN Jr: Regulation of gene expression by $\mathrm{pH}$ of the growth medium in Aspergillus nidulans. Mol Gen Genet 1986, 203(2):346-353.

60. Boase NA, Kelly JM: A role for creD, a carbon catabolite repression gene from Aspergillus nidulans, in ubiquitination. Mol Microbiol 2004, 53(3):929-940.

61. Pall ML: Adenosine 3', 5' -phosphate in fungi. Microbiol Rev 1981, 45:462-480.

62. Casas-Flores S, Rios-Momberg M, Rosales-Saavedra T, Martinez-Hernandez $\mathrm{P}$, Olmedo-Monfil V, Herrera-Estrella $A$ : Cross talk between a fungal blue-light perception system and the cyclic AMP signaling pathway. Eukaryot Cell 2006, 5(3):499-506

63. Friedl MA, Kubicek CP, Druzhinina IS: Carbon source dependence and photostimulation of conidiation in Hypocrea atroviridis. Appl Environ Microbiol 2008, 74(I):245-250.

64. Sestak S, Farkas V: Metabolic regulation of endoglucanase synthesis in Trichoderma reesei: participation of cyclic AMP and glucose-6-phosphate. Can J Microbiol I993, 39(3):342-347.

65. Thevelein JM: Fermentable sugars and intracellular acidification as specific activators of the RAS-adenylate cyclase signalling pathway in yeast: the relationship to nutrient-induced cell cycle control. Mol Microbiol I991, 5(6): I30 I- I 307.

66. Thevelein $\mathrm{JM}$, de Winde $\mathrm{J} \mathrm{H}$ : Novel sensing mechanisms and tar gets for the CAMP-protein kinase A pathway in the yeast Saccharomyces cerevisiae. Mol Microbiol 1999, 33(5):904-918.

67. Farkas V, Sestak S, Gresik M, Kolarova N, Labudova I, Bauer S: Induction of Cellulase in Trichoderma reesei grown on Lactose. Acta Biotechnologica 1987, 7(5):425-429.

68. Montenecourt BS, Nhlapo SD, Trimino-Vazquez H, Cuskey S, Schamhart DHJ, Eveleigh DE: Regulatory controls in relation to overproduction of fungal cellulases. Trends Biol Ferment 1981, 18:33-53.

69. Farkas V, Gresik M, Kolarova N, Sulova Z, Sestak S: Biochemical and physiological changes during photo-induced conidiation and derepression of cellulase synthesis in Trichoderma. In Trichoderma reesei cellulase: biochemistry, genetics, physiology, and application Edited by: Kubicek CP, Eveleigh DE, Esterbauer W, Steiner W, Kubicek-Pranz EM. Cambridge: Graham House; 1990:I39-I55.

70. Kolarova N, Haplova J, Gresik M: Light-activated adenyl cyclase from Trichoderma viride. FEMS Microbiol Lett I992, 72(3):275-278.

7I. Chen RE, Thorner J: Function and regulation in MAPK signaling pathways: lessons learned from the yeast Saccharomyces cerevisiae. Biochim Biophys Acta 2007, I 773(8): I 3 I I- I 340.

72. Gustin MC, Albertyn J, Alexander M, Davenport K: MAP kinase pathways in the yeast Saccharomyces cerevisiae. Microbiol Mol Biol Rev 1998, 62(4): I 264- I 300.

73. Kronstad J, De Maria AD, Funnell D, Laidlaw RD, Lee N, de Sa MM, Ramesh M: Signaling via cAMP in fungi: interconnections with mitogen-activated protein kinase pathways. Arch Microbiol 1998, I 70(6):395-404.

74. Nishimura M, Park G, Xu JR: The G-beta subunit MGB I is involved in regulating multiple steps of infection-related morphogenesis in Magnaporthe grisea. Mol Microbiol 2003, 50(I):23I-243.

75. Wang P, Perfect JR, Heitman J: The G-protein beta subunit GPB I is required for mating and haploid fruiting in Cryptococcus neoformans. Mol Cell Biol 2000, 20(I):352-362.

76. $\mathrm{Xu} J \mathrm{R}$, Hamer JE: MAP kinase and CAMP signaling regulate infection structure formation and pathogenic growth in the rice blast fungus Magnaporthe grisea. Genes Dev 1996 I O(2 I):2696-2706.

77. $\mathrm{Xu} \mathrm{JR}$, Staiger CJ, Hamer JE: Inactivation of the mitogen-activated protein kinase Mps I from the rice blast fungus prevents penetration of host cells but allows activation of plant defense responses. Proc Natl Acad Sci USA 1998 95(21): $12713-12718$.

78. Roman E, Arana DM, Nombela C, Alonso-Monge R, Pla J: MAP kinase pathways as regulators of fungal virulence. Trends Microbiol 2007, I 5(4): I8I-190.

79. Zhao $X$, Mehrabi $R, X u$ JR: Mitogen-activated protein kinase pathways and fungal pathogenesis. Eukaryot Cell 2007, 6(10): $|70|-17 \mid 4$

80. Mukherjee PK, Latha J, Hadar R, Horwitz BA: TmkA, a mitogenactivated protein kinase of Trichoderma virens, is involved in biocontrol properties and repression of conidiation in the dark. Eukaryot Cell 2003, 2(3):446-455.
8I. Olmedo-Monfil V, Mendoza-Mendoza A, Gomez I, Cortes C, Herrera-Estrella A: Multiple environmental signals determine the transcriptional activation of the mycoparasitism related gene prbl in Trichoderma atroviride. Mol Genet Genomics 2002, 267(6):703-7I2.

82. Reithner B, Schuhmacher R, Stoppacher N, Pucher M, Brunner K, Zeilinger S: Signaling via the Trichoderma atroviride mitogenactivated protein kinase Tmkl differentially affects mycoparasitism and plant protection. Fungal Genet Biol 2007.

83. Viterbo A, Harel M, Horwitz BA, Chet I, Mukherjee PK: Trichoderma mitogen-activated protein kinase signaling is involved in induction of plant systemic resistance. Appl Environ Microbiol 2005, 7 I ( I 0):624I-6246.

84. Li D, Bobrowicz P, Wilkinson HH, Ebbole DJ: A mitogen-activated protein kinase pathway essential for mating and contributing to vegetative growth in Neurospora crassa. Genetics 2005, I70(3): 109|-1104.

85. Pandey A, Roca MG, Read ND, Glass NL: Role of a mitogen-activated protein kinase pathway during conidial germination and hyphal fusion in Neurospora crassa. Eukaryot Cell 2004, 3(2):348-358

86. Fujimura M, Ochiai N, Oshima M, Motoyama T, Ichiishi A, Usami R, Horikoshi K, Yamaguchi I: Putative homologs of SSK22 MAPKK kinase and PBS2 MAPK kinase of Saccharomyces cerevisiae encoded by os- 4 and os- 5 genes for osmotic sensitivity and fungicide resistance in Neurospora crassa. Biosci Biotechnol Biochem 2003, 67(I):|86-19|

87. Jones CA, Greer-Phillips SE, Borkovich KA: The response regulator RRG-I functions upstream of a mitogen-activated protein kinase pathway impacting asexual development, female fertility, osmotic stress, and fungicide resistance in $\mathrm{Neu}$ rospora crassa. Mol Biol Cell 2007, I 8(6):2I23-2I 36.

88. Zhang Y, Lamm R, Pillonel C, Lam S, Xu JR: Osmoregulation and fungicide resistance: the Neurospora crassa os-2 gene encodes a HOG I mitogen-activated protein kinase homologue. Appl Environ Microbiol 2002, 68(2):532-538.

89. Vitalini MW de Paula RM, Goldsmith CS, Jones CA, Borkovich KA Bell-Pedersen D: Circadian rhythmicity mediated by temporal regulation of the activity of p38 MAPK. Proc Natl Acad Sci USA 2007, 104(46): 18223-18228.

90. Salwinski L, Miller CS, Smith AJ, Pettit FK, Bowie JU, Eisenberg D: The Database of Interacting Proteins: 2004 update. Nucleic Acids Res 2004:D449-45।.

91. Kim YK, Kawano T, Li D, Kolattukudy PE: A mitogen-activated protein kinase kinase required for induction of cytokinesis and appressorium formation by host signals in the conidia of Colletotrichum gloeosporioides. Plant Cell 2000, I 2(8): | 33 |- | 343.

92. Wang Y, Dohlman HG: Regulation of $\mathbf{G}$ protein and mitogenactivated protein kinase signaling by ubiquitination: insights from model organisms. Circ Res 2006, 99(I 2): I 305-I3 | 4.

93. Zeilinger S, Ebner A, Marosits T, Mach R, Kubicek CP: The Hypocrea jecorina HAP 2/3/5 protein complex binds to the inverted CCAAT-box (ATTGG) within the cbh2 (cellobiohydrolase IIgene) activating element. Mol Genet Genomics 200I, 266(I):56-63

94. Bokoch GM: Biology of the p2 I-activated kinases. Annu Rev Biochem 2003, 72:743-78I.

95. Dan I, Watanabe NM, Kusumi A: The Ste20 group kinases as regulators of MAP kinase cascades. Trends Cell Biol 200I, I I (5):220-230

96. Leeuw T, Wu C, Schrag JD, Whiteway M, Thomas DY, Leberer E: Interaction of a G-protein beta-subunit with a conserved sequence in Ste20/PAK family protein kinases. Nature 1998, 391(6663): $191-195$.

97. Leberer E, Dignard D, Harcus D, Thomas DY, Whiteway M: The protein kinase homologue Ste20p is required to link the yeast pheromone response $\mathbf{G}$-protein beta gamma subunits to downstream signalling components. EMBO J 1992, I I ( 3):48 I 5-4824.

98. Benton BK, Tinkelenberg A, Gonzalez I, Cross FR: Cla4p, a Saccharomyces cerevisiae Cdc42p-activated kinase involved in cytokinesis, is activated at mitosis. Mol Cell Biol 1997 I 7(9):5067-5076.

99. Kyriakis JM: Signaling by the germinal center kinase family of protein kinases. J Biol Chem 1999, 274(9):5259-5262. 
100. Wolanin PM, Thomason PA, Stock JB: Histidine protein kinases: key signal transducers outside the animal kingdom. Genome Biol 2002, 3( I 0):REVIEWS30I3.

I0I. Chang C, Clark K, Wang X, Stewart R: 'Two-component' ethylene signaling in Arabidopsis. Symp Soc Exp Biol 1998, 5 I:59-64.

102. Posas F, Takekawa M, Saito H: Signal transduction by MAP kinase cascades in budding yeast. Curr Opin Microbiol 1998 , I(2): $175-182$

03. Banno S, Noguchi R, Yamashita K, Fukumori F, Kimura M, Yamaguch I, Fujimura M: Roles of putative His-to-Asp signaling modules HPT-I and RRG-2, on viability and sensitivity to osmotic and oxidative stresses in Neurospora crassa. Curr Genet 2007. 5 I (3): I 97-208.

104. Hagiwara D, Matsubayashi Y, Marui J, Furukawa K, Yamashino T, Kanamaru K, Kato M, Abe K, Kobayashi T, Mizuno T: Characterization of the NikA histidine kinase implicated in the phosphorelay signal transduction of Aspergillus nidulans, with special reference to fungicide responses. Biosci Biotechnol Biochem 2007, 7 I(3):844-847.

105. Yoshimi A, Kojima K, Takano Y, Tanaka C: Group III histidine kinase is a positive regulator of Hog I-type mitogen-activated protein kinase in filamentous fungi. Eukaryot Cell 2005 4(I I): I820-I828.

106. Suzuki A, Kanamaru K, Azuma N, Kato M, Kobayashi T: GFP. Tagged Expression Analysis Revealed That Some Histidine Kinases of Aspergillus nidulans Show Temporally and Spatially Different Expression during the Life Cycle. Biosci Biotechnol Biochem 2008.

107. Vargas-Perez I, Sanchez O, Kawasaki L, Georgellis D, Aguirre J: Response regulators SrrA and SskA are central components of a phosphorelay system involved in stress signal transduc tion and asexual sporulation in Aspergillus nidulans. Eukaryo Cell 2007, 6(9): I570-I583.

108. Catlett NL, Yoder OC, Turgeon BG: Whole-genome analysis of two-component signal transduction genes in fungal pathogens. Eukaryot Cell 2003, 2(6): I| $5|-1|$ |6I.

109. Fankhauser C: The phytochromes, a family of red/far-red absorbing photoreceptors. J Biol Chem 200I, 276(I 5): I |453-I|456.

I I0. Froehlich AC, Noh B, Vierstra RD, Loros J, Dunlap JC: Genetic and molecular analysis of phytochromes from the filamentous fungus Neurospora crassa. Eukaryot Cell 2005, 4(I 2):2|40-2I 52.

III. Blumenstein A, Vienken K, Tasler R, Purschwitz J, Veith D, Frankenberg-Dinkel N, Fischer R: The Aspergillus nidulans phytochrome FphA represses sexual development in red light. Curr Biol 2005, I 5(20): | 833- |838.

I I2. Idnurm A, Heitman J: Photosensing fungi: phytochrome in the spotlight. Curr Biol 2005, I 5(20):R829-832.

I 13. Purschwitz J, Muller S, Kastner C, Schoser M, Haas H, Espeso EA Atoui A, Calvo AM, Fischer R: Functional and physical interaction of blue- and red-light sensors in Aspergillus nidulans. Curr Biol 2008, I 8(4):255-259.

I|4. Reinders A, Burckert N, Boller T, Wiemken A, De Virgilio C: Saccharomyces cerevisiae cAMP-dependent protein kinase controls entry into stationary phase through the Rim I 5p protein kinase. Genes Dev 1998, I 2( I 8):2943-2955.

II5. Corrochano LM: Fungal photoreceptors: sensory molecules for fungal development and behaviour. Photochem Photobiol Sci 2007, 6(7):725-736

I16. Herrera-Estrella A, Horwitz BA: Looking through the eyes of fungi: molecular genetics of photoreception. Mol Microbiol 2007, 64(I):5-15

I 17. Betina V, Farkas V: Sporulation and light-induced development in Trichoderma. Trichoderma \& Gliocladium. Edited by Harman GE and Kubicek CP, London: Taylor \& Francis 1998, I:75-94.

I 18. Farkas V, Betina V: The intracellular level of ATP during the photoinduced sporulation of Trichoderma viride. Folia Microbiol 1977, 22:438.

I 19. Farkas V, Sulova Z, Lehotsky J: Effect of light onthe concentration of adenine nucleotides in Trichoderma viride. Folia Microbiol 1985, I 3 1:3 | 7-320.

120. Gresik M, Kolarova N, Farkas V: Membrane potential, ATP, and cyclic AMP changes induced by light in Trichoderma viride. Exp Mycol 1988, I2:295-301

121. Sulova Z, Farkas V: Photoinduced conidiation in Trichoderm viride: A study with inhibitors. Folia Microbiol I991, 36:267-270.
122. Betina V, Zajacova J: Regulation of periodicity and intensity of photoinduced conidiation of Trichoderma viride. Folia Microbiol 1978, 23:453-459.

123. Dunlap JC, Loros J]: The neurospora circadian system. J Biol Rhythms 2004, I9(5):414-424.

124. Dunlap JC, Loros J]: How fungi keep time: circadian system in Neurospora and other fungi. Curr Opin Microbiol 2006 9(6):579-587

125. Liu Y, Bell-Pedersen D: Circadian rhythms in Neurospora crassa and other filamentous fungi. Eukaryot Cell 2006, 5(8): I I 84- I I 93.

126. Heintzen C, Loros JJ, Dunlap JC: The PAS protein VIVID defines a clock-associated feedback loop that represses light input, modulates gating, and regulates clock resetting. Cell $200 \mathrm{I}$, I 04(3):453-464.

127. Schwerdtfeger C, Linden H: VIVID is a flavoprotein and serves as a fungal blue light photoreceptor for photoadaptation. EMBO J 2003, 22( I 8):4846-4855

128. Casas-Flores S, Rios-Momberg M, Bibbins M, Ponce-Noyola P, Herrera-Estrella A: BLR-I and BLR-2, key regulatory elements of photoconidiation and mycelial growth in Trichoderma atroviride. Microbiology 2004, I 50:356 I-3569.

129. Esquivel-Naranjo EU, Herrera-Estrella A: Enhanced responsiveness and sensitivity to blue light by blr-2 overexpression in Trichoderma atroviride. Microbiology 2007, I 53(Pt I I):3909-3922.

130. Berrocal-Tito GM, Esquivel-Naranjo EU, Horwitz BA, HerreraEstrella A: Trichoderma atroviride PHRI, a fungal photolyase responsible for DNA repair, autoregulates its own photoinduction. Eukaryot Cell 2007, 6(9):1682-1692.

|3|. Berrocal-Tito G, Sametz-Baron L, Eichenberg K, Horwitz BA, Herrera-Estrella A: Rapid blue light regulation of a Trichoderma harzianum photolyase gene. J Biol Chem 1999 , 274(20): | 4288-|4294.

132. Berrocal-Tito GM, Rosales-Saavedra T, Herrera-Estrella A, Horwitz BA: Characterization of blue-light and developmental regulation of the photolyase gene phrl in Trichoderma harzianum. Photochem Photobiol 2000, 7I(5):662-668.

133. Griffin EA Jr, Staknis D, Weitz Cl: Light-independent role of CRYI and CRY2 in the mammalian circadian clock. Science I999, 286(5440):768-77|.

134. He Q, Cha J, He Q, Lee HC, Yang Y, Liu Y: CKI and CKII mediate the FREQUENCY-dependent phosphorylation of the WHITE COLLAR complex to close the Neurospora circadian negative feedback loop. Genes Dev 2006, 20( I 8):2552-2565.

135. Mooney JL, Hassett DE, Yager LN: Genetic analysis of suppressors of the veAl mutation in Aspergillus nidulans. Genetics 1990, I 26(4):869-874.

136. Mooney JL, Yager LN: Light is required for conidiation in Aspergillus nidulans. Genes Dev 1990, 4(9): |473-| 482

137. Sprote $P$, Brakhage $A A$ : The light-dependent regulator velvet $A$ of Aspergillus nidulans acts as a repressor of the penicillin biosynthesis. Arch Microbiol 2007, I 88(I):69-79.

138. Arpaia G, Carattoli A, Macino G: Light and development regulate the expression of the albino-3 gene in Neurospora crassa. Dev Biol 1995, I 70(2):626-635.

139. Li C, Schmidhauser TJ: Developmental and photoregulation of al- $I$ and al-2, structural genes for two enzymes essential for carotenoid biosynthesis in Neurospora. Dev Biol 1995, I 69(I):90-95

140. Rosales-Saavedra T, Esquivel-Naranjo EU, Casas-Flores S, MartinezHernandez P, Ibarra-Laclette E, Cortes-Penagos C, Herrera-Estrella A: Novel light-regulated genes in Trichoderma atroviride: a dissection by cDNA microarrays. Microbiology 2006, I 52(Pt I I):3305-3317.

[4I. Rasmussen H, Barrett P, Smallwood J, Bollag W, Isales C: Calcium ion as intracellular messenger and cellular toxin. Environ Health Perspect 1990, 84:17-25

142. Bootman MD, Collins T], Peppiatt CM, Prothero LS, MacKenzie L, De Smet P, Travers M, Tovey SC, Seo JT, Berridge MJ, et al:: Calcium signalling - an overview. Semin Cell Dev Biol 200I, I 2(I):3-I0.

143. Berridge MJ, Bootman MD, Roderick HL: Calcium signalling: dynamics, homeostasis and remodelling. Nat Rev Mol Cell Biol 2003, 4(7):517-529.

144. Sanders D, Pelloux J, Brownlee C, Harper JF: Calcium at the crossroads of signaling. Plant Cell 2002, I 4(Suppl):S40 I-4I7. 
145. Cooper DM, Mons N, Karpen JW: Adenylyl cyclases and the interaction between calcium and cAMP signalling. Nature 1995, 374(652I):42I-424.

146. Kraus PR, Heitman J: Coping with stress: calmodulin and calcineurin in model and pathogenic fungi. Biochem Biophys Res Commun 2003, 3II(4): II5I-II57.

147. Prokisch H, Yarden O, Dieminger M, Tropschug M, Barthelmess IB Impairment of calcineurin function in Neurospora crassa reveals its essential role in hyphal growth, morphology and maintenance of the apical Ca2+ gradient. Mol Gen Genet 1997 , 256(2): 104-II4.

148. Yang Y, Cheng $P$, Zhi G, Liu Y: Identification of a calcium/calmodulin-dependent protein kinase that phosphorylates the Neurospora circadian clock protein FREQUENCY. J Biol Chem 200I, 276(44):4I064-4I072.

149. Rana RS, Hokin LE: Role of phosphoinositides in transmembrane signaling. Physiol Rev 1990, 70(I): I I5-164.

150. Heinz DW, Essen LO, Williams RL: Structural and mechanistic comparison of prokaryotic and eukaryotic phosphoinositidespecific phospholipases C. J Mol Biol 1998, 275(4):635-650.

I5I. NCBI CDD subgroup hierarchy for cd00876 (Ras-proteins) [http://www.ncbi.nlm.nih.gov/Structure/cdd/cddsrv.cgi?uid=57935]

152. Zhang B, Zhang Y, Shacter E, Zheng Y: Mechanism of the guanine nucleotide exchange reaction of Ras GTPase - evidence for a GTP/GDP displacement model. Biochemistry 2005, 44(7):2566-2576.

153. Overbeck AF, Brtva TR, Cox AD, Graham SM, Huff SY, Khosravi-Far R, Quilliam LA, Solski PA, Der C): Guanine nucleotide exchange factors: activators of Ras superfamily proteins. Mol Reprod Dev 1995, 42(4):468-476.

154. Quilliam LA, Rebhun JF, Castro AF: A growing family of guanine nucleotide exchange factors is responsible for activation of Ras-family GTPases. Prog Nucleic Acid Res Mol Biol 2002, 7I:391-444.

155. Broek D, Samiy N, Fasano O, Fujiyama A, Tamanoi F, Northup J, Wigler M: Differential activation of yeast adenylate cyclase by wild-type and mutant RAS proteins. Cell 1985, 4I(3):763-769.

156. Toda T, Uno I, Ishikawa T, Powers S, Kataoka T, Broek D, Cameron $\mathrm{S}$, Broach J, Matsumoto K, Wigler M: In yeast, RAS proteins are controlling elements of adenylate cyclase. Cell 1985, 40(1):27-36.

157. Fillinger S, Chaveroche MK, Shimizu K, Keller N, d'Enfert C: cAMP and ras signalling independently control spore germination in the filamentous fungus Aspergillus nidulans. Mol Microbiol 2002, 44(4): $1001-1016$

158. Levin DE: Cell wall integrity signaling in Saccharomyces cerevisiae. Microbiol Mol Biol Rev 2005, 69(2):262-29l.

159. InterProscan server [http://www.ebi.ac.uk/InterProScan/]

160. NCBI CDD (conserved domain database) search server [http://www.ncbi.n/m.nih.gov/Structure/cdd/wrpsb.cgi]

161. Shimizu K, Hicks JK, Huang TP, Keller NP: Pka, Ras and RGS protein interactions regulate activity of AflR, a $\mathrm{Zn}(\mathrm{II}) 2 \mathrm{Cys} 6$ transcription factor in Aspergillus nidulans. Genetics 2003, 165(3): 1095-I 104.

162. Fortwendel JR, Panepinto JC, Seitz AE, Askew DS, Rhodes JC: Aspergillus fumigatus ras $A$ and ras $B$ regulate the timing and morphology of asexual development. Fungal Genet Biol 2004 4I(2): 129-139.

163. Osherov N, May G: Conidial germination in Aspergillus nidulans requires RAS signaling and protein synthesis. Genetics 2000, I 55(2):647-656.

164. Som T, Kolaparthi VS: Developmental decisions in Aspergillus nidulans are modulated by Ras activity. Mol Cell Biol 1994, 14(8):5333-5348

165. Genome databases at the Joint Genome Institute of DOE (Department of Energy, US) [http://genome.jgi-psf.org/]

166. Genome databases of the Fungal Genome Initiative at the Broad institute [http://www.broad.mit.edu/annotation/]

167. Aspergillus nidulans genome database at BROAD institute [http://www.broad.mit.edu/annotation/genome/aspergillus group/ MultiHome.html]

168. Neurospora crassa genome database at BROAD institute [http://www.broad.mit.edu/annotation/genome/neurospora/ Home.html]

169. Magnaporthe grisea genome database at BROAD institute.
170. Marchler-Bauer A, Anderson JB, DeWeese-Scott C, Fedorova ND, Geer LY, He S, Hurwitz DI, Jackson JD, Jacobs AR, Lanczycki CJ, et al: CDD: a curated Entrez database of conserved domain alignments. Nucleic Acids Res 2003, 3I(I):383-387.

17I. NCBI Blast server [http://www.ncbi.nlm.nih.gov/BLAST/]

172. Altschul SF, Madden TL, Schaffer AA, Zhang J, Zhang Z, Miller W, Lipman DJ: Gapped BLAST and PSI-BLAST: a new generation of protein database search programs. Nucleic Acids Res 1997, 25(I7):3389-3402.

173. Thompson JD, Gibson TJ, Plewniak F, Jeanmougin F, Higgins DG: The CLUSTAL_ $X$ windows interface: flexible strategies for multiple sequence alignment aided by quality analysis tools. Nucleic Acids Res 1997, 25(24):4876-4882.

174. Rzhetsky A, Nei M: Statistical properties of the ordinary leastsquares, generalized least-squares, and minimum-evolution methods of phylogenetic inference. J Mol Evol 1992, 35(4):367-375.

175. Felsenstein J: Confidence limits on phylogenies: An approach using the bootstrap. Evolution 1985, 39:783-791.

176. Zuckerkandl E, Pauling L: Molecules as documents of evolutionary history. J Theor Biol 1965, 8(2):357-366.

177. Nei M, Kumar S: Molecular Evolution and Phylogenetics. New York: Oxford University Press; 2000.

178. Saitou N, Nei M: The neighbor-joining method: a new method for reconstructing phylogenetic trees. Mol Biol Evol 1987, 4(4):406-425.

179. Tamura K, Dudley J, Nei M, Kumar S: MEGA4: Molecular Evolutionary Genetics Analysis (MEGA) software version 4.0. Mo Biol Evol 2007, 24(8): 1596-1599.

180. West AH, Stock AM: Histidine kinases and response regulator proteins in two-component signaling systems. Trends Biochem Sci 200I, 26(6):369-376.

Publish with BioMed Central and every scientist can read your work free of charge

"BioMed Central will be the most significant development for disseminating the results of biomedical research in our lifetime. "

Sir Paul Nurse, Cancer Research UK

Your research papers will be:

- available free of charge to the entire biomedical community

- peer reviewed and published immediately upon acceptance

- cited in PubMed and archived on PubMed Central

- yours - you keep the copyright
BioMedcentral 